\title{
Expectations of Returns and Expected Returns
}

\section{Citation}

Greenwood, Robin Marc, and Andrei Shleifer. 2014. "Expectations of Returns and Expected Returns." Review of Financial Studies 27 (3) (March 1): 714-746. doi:10.1093/rfs/hht082. http:// dx.doi.org/10.1093/rfs/hht082.

\section{Published Version}

doi:10.1093/rfs/hht082

\section{Permanent link}

http://nrs.harvard.edu/urn-3:HUL.InstRepos:11880390

\section{Terms of Use}

This article was downloaded from Harvard University's DASH repository, and is made available under the terms and conditions applicable to Open Access Policy Articles, as set forth at http:// nrs.harvard.edu/urn-3:HUL.InstRepos:dash.current.terms-of-use\#OAP

\section{Share Your Story}

The Harvard community has made this article openly available.

Please share how this access benefits you. Submit a story.

Accessibility 
NBER WORKING PAPER SERIES

EXPECTATIONS OF RETURNS AND EXPECTED RETURNS

\author{
Robin Greenwood \\ Andrei Shleifer \\ Working Paper 18686 \\ http://www.nber.org/papers/w18686
}

\author{
NATIONAL BUREAU OF ECONOMIC RESEARCH \\ 1050 Massachusetts Avenue \\ Cambridge, MA 02138 \\ January 2013
}

We thank Yueran Ma for outstanding research assistance and Josh Coval, Jared Dourdeville, Sam Hanson, Owen Lamont, Stefan Nagel, Joshua Schwartzstein, Adi Sunderam, Annette Vissing-Jorgensen, Jessica Wachter, Fan Zhang and seminar participants at UC Berkeley and the NBER for helpful suggestions. We are grateful to the Survey Research Center at the University of Michigan for providing access to their data. The views expressed herein are those of the authors and do not necessarily reflect the views of the National Bureau of Economic Research.

NBER working papers are circulated for discussion and comment purposes. They have not been peerreviewed or been subject to the review by the NBER Board of Directors that accompanies official NBER publications.

(C) 2013 by Robin Greenwood and Andrei Shleifer. All rights reserved. Short sections of text, not to exceed two paragraphs, may be quoted without explicit permission provided that full credit, including (c) notice, is given to the source. 
Expectations of Returns and Expected Returns

Robin Greenwood and Andrei Shleifer

NBER Working Paper No. 18686

January 2013

JEL No. G02,G12,G14

\begin{abstract}
$\underline{\text { ABSTRACT }}$
We analyze time-series of investor expectations of future stock market returns from six data sources between 1963 and 2011. The six measures of expectations are highly positively correlated with each other, as well as with past stock returns and with the level of the stock market. However, investor expectations are strongly negatively correlated with model-based expected returns. We reconcile the evidence by calibrating a simple behavioral model, in which fundamental traders require a premium to accommodate expectations shocks from extrapolative traders, but markets are not efficient.
\end{abstract}

\author{
Robin Greenwood \\ Harvard Business School \\ Baker Library 267 \\ Soldiers Field \\ Boston, MA 02163 \\ and NBER \\ rgreenwood@hbs.edu \\ Andrei Shleifer \\ Department of Economics \\ Harvard University \\ Littauer Center M-9 \\ Cambridge, MA 02138 \\ and NBER \\ ashleifer@harvard.edu
}




\section{Introduction}

Over the last 20 years, increasing amounts of data on investor expectations of stock market returns have become available. We analyze these expectations obtained from six data sources: the Gallup investor survey, the Graham-Harvey Chief Financial Officer surveys, the American Association of Individual Investors survey, the Investor Intelligence survey of investment newsletters, Robert Shiller's investor survey, and the Survey Research Center at the University of Michigan. We also compare these investor expectations of returns with what financial economists call "expected returns" (hereafter ER) computed from aggregate data on dividends, consumption, and market valuations. The measures of ER we examine include the dividend price ratio, but also variables proposed by Campbell and Cochrane (1999) and Lettau and Ludvigson (2001). These ER measures seek to capture fluctuations in investors' required returns over time.

We begin with three findings about the expectations of returns. First, the six measures of expectations of stock market returns are highly positively correlated with each other. Second, these measures of investor expectations tend to be extrapolative: they are positively correlated with past stock market returns, as well as with the level of the stock market (i.e., they are positively correlated with the price-dividend ratio). Third, these measures of expectations are also highly correlated with investor inflows into mutual funds. Together, these results suggest that survey measures of investor expectations are not meaningless noise, but rather reflections of widely shared beliefs about future market returns, which tend to be extrapolative in nature.

We next compare these measures of investor expectations to four standard measures of ER. Two findings stand out. First, although results differ across variables, generally speaking ER and expectations of returns are negatively correlated with each other. When investors say that they expect stock market returns to be high, model-based expected returns are low. In rational expectations models, expectations of stock market returns and model-based measures of ER should be perfectly positively 
correlated. We can reject this hypothesis with considerable confidence. This evidence is inconsistent with the view that expectations of stock market returns reflect the beliefs or requirements of a representative investor in a rational expectations model.

Second, both expectations of returns and ER predict future stock market returns, but with opposite signs. When ER is high, market returns are on average high; when expectations of returns are high, market returns are on average low.

Reconciling all the evidence poses a significant challenge. One possibility, pursued by all the authors constructing measures of ER, is that investors hold rational expectations and ER measure true but not directly observed expectations of market returns. But this possibility seems broadly inconsistent with the facts that the directly observed expectations of market returns 1) are highly correlated across data sources, 2) have a clear extrapolative structure, and 3) are negatively correlated with available measures of ER. The expectations of investors captured by the surveys are not at all the expectations obtained indirectly from rational expectations models.

A second possibility is that when investors say "high," they mean "low." For example, perhaps when investors report high expectations of market returns, they mean high expected growth of fundamentals, in which case their true expectations of market returns are low. This conjecture seems inconsistent with the obvious fact that respondents in the surveys we cover are active investors, and even CFOs, and they are asked directly about their expectations of stock market returns, not changes in fundamentals. The conjecture is also inconsistent with the high correlation between investors' reported expectations and their actual behavior, as measured by the flows that retail investors direct into mutual funds.

The third possibility is that survey measures of expectations of returns capture actual expectations of a broad segment of investors, and that these investors extrapolate returns and act on their 
beliefs, as in models of Cutler, Poterba, and Summers (1990) and DeLong et al. (1990b). But in this case, what do the standard empirical measures of ER reflect, if not these investors' expectations of market returns?

To pursue this question, we perform a simple exercise. We construct a behavioral model that is a special case of Cutler, Poterba, and Summers (1990), in which a subgroup of investors hold extrapolative expectations, and another subgroup are fundamentalists whose demand is inversely related to market valuations. Fundamentalists can be interpreted as rational investors with limited risk bearing capacity, although a full dynamic model with extrapolative expectations and rational investors has not been worked out. In this model, aggregate risk is constant, but the amount of risk that must be held by the fundamentalists varies over time. This is because the fundamentalists must accommodate the timevarying demand of the extrapolative traders.

The CPS model has a very simple structure, which makes it easy to solve and calibrate. We calibrate the model using our findings on actual expectations of extrapolative investors. Our main question is whether, in such a model, the standard measures of ER have forecasting power for market returns? Using simulated data, the answer is a clear yes. This suggests that the forecasting powers of ER need not from changes in required risk premia in a representative agent model. A high dividend price ratio may predict high future stock market returns not because investors in aggregate have become more risk averse, but because a subset of investors in the market demand a premium for absorbing stock sold by positive feedback traders who believe future market returns will be low.

There is a small but vibrant literature using data on actual expectations to test economic hypotheses. Some of the earlier work focused on exchange rates, and found an extrapolative component in expectations data (Dominguez 1986, Frankel and Froot 1987). Robert Shiller and his coauthors have used expectations data to analyze bubbles in markets ranging from Japanese stocks (Shiller, Kon-Ya, 
and Tsutsui 1996) to American housing (Case, Shiller, and Thompson 2012). For equities, the papers closer to our work are Amronin and Sharpe (2008) and Bacchetta, Mertens, and Wincoop (2009), who find, as we also document below, that return expectations and expectational errors are related to dividend yields. Finally, several papers present evidence that investors' personal experiences influence their expectations, e.g., Vissing-Jorgensen (2004), Malmendier and Nagel (2011), and Nagel (2012). Our contribution to the literature is to put several data sources together, to present data on the structure of investor expectations about stock market returns in a systematic way, and to compare these data to expected returns constructed by financial economists.

The next section describes our data. Section 3 presents the basic statistical description of the data on expectations of returns. Section 4 compares investors' expectations of returns with the standard ER measures. Section 5 describes a simple behavioral model and performs a calibration exercise, which allows some tentative conclusions on how the various pieces of evidence can be reconciled.

\section{Measuring Investor Expectations}

We collect survey results from six major sources: the Gallup investor survey, Graham and Harvey's surveys of CFOs, the American Association of Individual Investors survey, Investor Intelligence's summary of professional investors' beliefs, Shiller's survey on individual investors, and the University of Michigan survey of US consumers. Below we describe each of the series individually. An online appendix lists the individual time-series and sources, except Investor Intelligence for which we purchased a license.

\section{Gallup}


The Gallup survey, conducted between 1996 and 2012, asks individual investors about their experiences in the economy and in the stock market, as well as their beliefs about the economy and the stock market over the next 12 months. Participants change from survey to survey. In the early sample years, the survey was run monthly with samples exceeding 700 respondents, but there are some gaps in later years, the largest being November 2009 through February 2011 when the survey was discontinued before being restarted in March 2011. The individual respondent data, also studied in Vissing-Jorgensen (2004) is available between 1996 and 2007. We use Gallup to construct our benchmark source of expectations, because of Gallup's large sample size and consistent methodology.

Ideally, each monthly instance of the survey would have asked participants to specify the percentage return they expect to earn in the stock market. Instead, the survey asked participants whether they were "very optimistic," "optimistic," “neutral," "pessimistic," or "very pessimistic" about stock returns over the next year. Gallup sent us the percentage of participants in each group, which is available beginning in October 1996. In addition, more precise quantitative estimates of survey participants' beliefs are available between September 1998 and May 2003. During this time, participants were asked to give an estimate of the percentage return they expect on the market over the next 12 months. For an even shorter time period between 1998 and 2000, participants were also asked to indicate "the minimum acceptable rate of return" on their portfolio over the next twelve months. ${ }^{1}$ The former can be used as a proxy for expectations, while the latter can be used as a measure of required returns, albeit for a short sample period.

Panel A of Figure 1 shows the Gallup investor expectations series. The solid line denotes our measure of expectations:

$$
\text { Gallup }=\% \text { Bullish }-\% \text { Bearish, }
$$

\footnotetext{
${ }^{1}$ We constructed this variable ourselves using the mean of participant-level survey responses.
} 
the percentage of investors who are "very optimistic" or "optimistic" about the future performance of the stock market, minus the percentage of investors who are "pessimistic" or "very pessimistic". The dashed line between 1996 and 2003 shows the average expectation of return on the stock market. These two series are $84 \%$ correlated in levels and $65 \%$ correlated in one-month changes, indicating that the qualitative measure of investor beliefs about market returns is capturing the same variation as the quantitative measure.

For additional comparison, the short dashed line between 1998 and 2000 shows investors reported "minimum acceptable returns" which closely track the two other series during the short window of overlap. On average, minimum acceptable returns are 1.74 percentage points lower than actual expectations of returns. The $87 \%$ correlation between minimum acceptable returns and expectations of returns suggests that investors actually understand the questions, but also see expected returns and minimum required returns as driven by similar factors.

One can use the strong correlation between the time-series to rescale Gallup from Eq. (1) to estimate a corresponding percentage expectation of return. If we project Gallup on the percentage expected return, the fitted return values suggest that expectations of one-year returns vary between a low of 3.9\% (February 2009) and a high of 14.27\% (January 2000). An equal share of investors reporting being "bullish" and "bearish" (i.e., Gallup=0) corresponds to an expectation of $8.5 \%$, close to the average one-year return of $8.1 \%$ on the CRSP value-weighted stock market during the 1997-2011.

\section{Graham and Harvey}

Since 1998, John Graham and Campbell Harvey have been surveying chief financial officers (CFOs) of major U.S. corporations. The survey solicits CFO views regarding the US economy and the performance of their firms, as well as their expectations of returns on the U.S. stock market over the 
next twelve months. ${ }^{2}$ Expectations of the stock market are available beginning in October 2000 . The survey contains answers from more than 200 respondents each quarter. Graham and Harvey publish summary statistics for each question on each survey.

We obtain average expected returns from these surveys from John Graham's website, and plot the resulting time-series in Figure 2, alongside the Gallup series. As can be seen, CFO expectations are highly correlated with expectations reported in the Gallup survey, with a correlation coefficient of 0.77 . Especially for CFOs, it is unreasonable to argue that they do not know what the market return is.

\section{American Association of Individual Investors}

The American Association of Individual Investors Investor Sentiment Survey measures the percentage of individual investors who are bullish, neutral, or bearish on the stock market for the next six months. The survey is administered weekly to members of the American Association of Individual Investors. We construct a time-series of investor expectations by subtracting the percentage of "bearish" investors from the percentage of "bullish" investors between 1987 when the survey first started and December 2011. Because most of our other data are available monthly, we work with monthly averages of this data. As shown in Panel A of Figure 3, the American Association expectations are strongly positively correlated with the Gallup time-series.

\section{Investors' Intelligence Newsletter Expectations}

Since 1963, "Investors Intelligence," has been summarizing the outlook of over 120 independent financial market newsletters. Their survey was conducted monthly for 1963, then bi-weekly through

\footnotetext{
${ }^{2}$ In addition to asking CFOs for their "best guess" of the performance of the stock market, Graham and Harvey also ask for 90\% confidence intervals. See Ben-David, Graham, and Harvey (2012) for further discussion.
} 
June 1969 when it was shifted to weekly, which it remained through 2011. Data from this survey has been previously studied by Clarke and Statman (1998).

The editors of the survey classify each newsletter as having "bullish," "bearish" or "neutral" forecasts of returns on the stock market over the near term. Since newsletters disappear and new ones are started, the editors of the survey watch the national business press looking for references to new letters, but wait a few months after introduction before including any new source. Only four editors have been involved in classifying newsletters since inception of the survey in 1963, ensuring consistent treatment over time. ${ }^{3}$

In line with our methodology for the Gallup and American Association series, we summarize their measure as the difference between the percentage of newsletters that are "bullish" and the percentage that are "bearish." We obtain the time-series of their expectations measure, which we plot alongside the Gallup series in Panel B of Figure 3. For months in which the survey was conducted multiple times, we use the average.

The Investors' Intelligence series exhibits more short-term volatility than our other measures of investor expectations. Nevertheless, the correlation with the other series is high: $60 \%$ with Gallup, $55 \%$ with American Association, and 64\% with CFO expectations.

\section{Shiller's Survey}

Started by Robert Shiller in the 1980s, the Investor Behavior Project at Yale University releases surveys of individual investor confidence in the stock market. We use the one-year individual confidence index, measured as the percentage of individual investors who expect the market to rise over

\footnotetext{
${ }^{3}$ There are relatively few studies analyzing the structure of newsletter expectations or their performance in forecasting the equity premium. For one prominent example, see Graham and Harvey (1996) who analyze the newsletters covered by the Hulbert Financial Digest.
} 
the following year. ${ }^{4}$ Data are available only sporadically between 1999 and July 2001. After that, the surveys are conducted monthly. As can be seen in Figure 3, Shiller is 39\% correlated with the Gallup survey.

\section{Michigan Survey}

Survey Research Center at the University of Michigan has been surveying US consumers since 1946 about their experiences and beliefs regarding the economy and their consumption habits. For 22 of the surveys, occurring between November 2000 and October 2005, respondents were asked about their beliefs about expected returns on the broader stock market. For a subset of these surveys, respondents are asked about 12-month returns, but for all 22 they are asked about their beliefs regarding annualized expected returns over the next two to three years. Respondents are occasionally polled more than once, but never more than two times. Because time series on individuals consist of at most two data points, we restrict our attention to the survey averages. Amronin and Sharpe (2008) also rely on the Michigan data in their study of household expectations.

The Survey Research Center provided us the raw survey data from these surveys and we compute average expected returns for each survey date. As can be seen in Figure 3, Michigan expectations are $61 \%$ correlated with expectations from the Gallup survey. Due to the limited number of time-series observations (there are only 22 data points), however, we interpret results using this series with more caution.

\section{Rescaling Investor Expectations}

\footnotetext{
${ }^{4}$ See http://icf.som.yale.edu/stock-market-confidence-indices-explanation and Shiller (2000).
} 
To keep things simple, for most of our statistical tests we use the unadjusted raw time series of investor expectations described above. However, but for the Graham-Harvey and Michigan surveys, the expectations are all in different units, making direct comparisons between them difficult, as well making it difficult to assert the economic significance of their predictive power for stock returns. For this reason, we create rescaled versions of each expectations measure, which we denote by an asterisk (e.g., Gallup*). We do this by projecting the Gallup \% stock return expectation (available between 1999 and 2003) onto each series. ${ }^{5}$ We then use the fitted regression coefficients to rescale each series. This has the effect of simply multiplying by a constant and adding a (different) constant.

Panel B of Table 1 summarizes the rescaled series. Note that GrahamHarvey and Michigan do not change at all because they are already in units of annual percent. Panel B shows that the average expected return, now including all series, ranges from 6.0 percent per annum (Graham-Harvey) to $10.6 \%$ per annum (Shiller). In comparing surveys, we must bear in mind that all of the series cover different time periods. The standard deviation of expected stock returns is similar across all measures, ranging from 1.3 percent (American Association) to 2.3 percent (Gallup).

\section{Critiques of Survey Data}

Two common criticisms of survey data on expected returns are that (1) they are noisy and thus meaningless, and (2) people do not mean what they say, or relatedly, that survey responses are strongly dependent on framing and language. With regard to the first point, we have noted that although there is some noise in the individual surveys, responses of return expectations tend to be highly correlated with each other.

\footnotetext{
${ }^{5}$ We have also experimented with projecting the Graham-Harvey expectations series onto each series. This relies on slightly fewer data points and produces expectations of returns that are slightly higher. Similarly, we could rescale using the Michigan data.
} 
The second point is that financial economists are generally skeptical about survey data. Lamont (2003) submits, for example, that "survey data about expectations and beliefs is the weakest form data, just one rung up in the quality ladder above anecdotes." Cochrane (2011) maintains that "survey reports of people's expectations are certainly unsettling. However, surveys are sensitive to language and interpretation."

A simple consistency check for survey expectations data is to ask whether investors behave in a manner that is consistent with what they report in the surveys. This can be done by examining mutual fund flows. We obtain a measure of investor inflows into equity-oriented mutual funds from Investment Company Institute. We scale the net dollar inflows in each month by the aggregate capitalization of the US stock market. Although flows do not directly measure expectations, Figure 4 shows that they are strongly positively correlated with investor expectations. In addition, consistent with prior evidence, aggregate flows are strongly influenced by past returns (not tabulated, see Sirri and Tufano 1998 and Frazzini and Lamont 2008, Lamont 2012). The evidence thus suggests that investors act in line with their reported expectations - when they report high expected market returns, they also tend to be purchasing equity mutual funds.

We also consider the objection that investors are confused by the questions. One possibility is that investors believe they are answering questions about current or future fundamentals rather than the performance of the stock market. Suppose, following Cochrane (2011), that investors report not their true beliefs, but instead their "risk neutral" equivalents, whereby they report their expectations of future discounted cash flows. Adopting this logic, when investors say "high cash flow" they mean "low required returns". But the survey questions we analyze here explicitly ask about future stock market returns. Gallup, for example, asks survey participants about their beliefs on the "performance" of the stock market over the next 12 months; the Michigan survey asks "what is the average annual percentage 
rate of return that you would expect to earn over the next 2 to 3 years?"; CFOs in the Graham-Harvey survey are asked "during the next year, I expect the S\&P 500 return will be..." If investors were answering these questions using risk neutral equivalents, it would mean that they would simply report the risk-free rate. In light of these observations, it is more plausible to conclude that investors understand the questions, and to take their answers at face value.

\section{Correlation between different measures of investor expectations}

In Table 2, we show partial correlations between the different measures of investor expectations. The table summarizes the visual impressions from Figures 1, 2 and 3 . The average correlation is $43 \%$ and the maximum correlation is $77 \%$ (between Gallup and Graham-Harvey). All correlations are positive, but for the correlation between Michigan and Graham Harvey (the correlation is zero) and between Michigan and Shiller (the correlation is significantly negative). The high degree of correlation between the time series is impressive given the variety of different investors being surveyed for their expectations - from individuals to chief financial officers to professional investors.

At the bottom row of the table, we show the correlations between investor expectations and flows. Again, the correlation is positive and statistically significant in nearly every case. The only exception is the Michigan survey, which is strongly positively correlated with Gallup and American Association, but uncorrelated or negatively correlated with the other surveys. For this survey, we should bear in mind, however, the limited number of observations $(\mathrm{N}=22)$.

\section{Determinants of Investor Expectations}

Our next task is to describe the time series structure of investor expectations. In this, we are guided by past research. Several empirical studies in finance have emphasized the role of extrapolative 
expectations in explaining behavior of security prices (e.g., Barsky and DeLong 1993, Cutler, Poterba, and Summers 1991, Lakonishok, Shleifer, and Vishny 1994). Theoretical papers in behavioral finance also often recognize the role of extrapolation (Barberis, Shleifer, and Vishny 1998, Campbell and Kyle 1993, Cutler, Poterba, and Summers 1990b, DeLong et al. 1990b, Fuster, Laibson, and Mendel 2010). Prior work on direct measures of expectations, and of trading behavior guided by expectations, also points to the importance of extrapolation (Frankel and Froot 1987, 1988, Hurd et al. 2009, Shiller 2000, Case et al. 2012, Yagan 2012). These earlier studies guide our empirical analysis.

We start in Figure 5 by plotting the Gallup measure of investor expectations against past 12month returns on the US stock market. There appears to be a high positive correlation between investor expectations and past returns.

Table 3 presents results for the corresponding time-series specifications

$$
\operatorname{Exp}_{t}=a+b R_{t-k}+c P_{t}+d Z_{t}+u_{t}
$$

where $R$ denotes the past $k$-period cumulative raw return on the stock market, $P$ denotes the price level (either $\log$ price of the S\&P 500 or the $\log$ price-dividend ratio) and $Z$ denotes other variables. In the table, we show specifications in which $R$ denotes the past 12-month return, but the results that follow are not sensitive to changing the horizon between 3- and 24-months. In other words, the findings obtain as long as we focus on recent returns. ${ }^{6}$

In time-series regressions of this sort, both the left- and right-hand side variables are persistent, leading to positive autocorrelation of the error term $u_{t}{ }^{7}$ The standard correction is to report $t$-statistics based on Newey and West (1987), allowing for a sufficient number of lags. In our case, this is somewhat complicated by the sporadic sampling of some of the time-series. For example, the Graham-

\footnotetext{
${ }^{6}$ Results vary somewhat across the different expectations measures. The evidence suggests that measures of investor expectations based on individuals are slightly more sensitive to recent past returns (3-months as opposed to, say, the past 24months) than the measures based on CFOs and professional investors.

7 Another concern is that in columns (1)-(6) of the table, the log price level is not stationary; for this reason we show regressions also using the dividend-price ratio.
} 
Harvey survey measures are released quarterly, while the Gallup data have short episodes of missing data. We follow Datta and Du (2012), who suggest a simple modification of the Newey and West procedure in which the researcher treats the data as if it is equally spaced.

Although the results differ across measures, Table 3 shows that investor expectations are well explained by two variables. First, when recent past returns are high, investors expect higher returns going forward. Second, even after controlling for recent returns, investor expectations of future returns are positively correlated with the level of prices. These results appear irrespective of how investor expectations are measured. Across the columns of Panel A of Table 3, the average $R$-squared is 0.40 .

Because the survey expectations measures all have different units, the regression coefficients must be rescaled in order to compare them across different survey types. Consider the first regression in column (1): the coefficient on lagged returns is 33.71 while the coefficient on the price level is 16.88 . An increase in the price level over the past year of 20 percent (roughly one standard deviation of annual returns over the period on which the regression is based) increases the Gallup measure of expectations by 20.5 units. Rescaling this to a percentage return, this is approximately 2.10 percentage points, which is approximately one standard deviation. More broadly, across all specifications, the coefficients on lagged price level tend to be lower, but the same order of magnitude, than the coefficients on the 12 month past return. Because the price level, in log terms, is essentially just the sum of all past returns, this simply says that more recent returns exert a stronger influence on investor expectations.

In addition to past returns and price levels, we experiment with several proxies for fundamentals, including past and current changes in log dividends, past and current changes in log earnings, as well as measures of macroeconomic conditions such as current and lagged GDP growth, industrial production, and the unemployment rate. In further untabulated tests we have also attempted to use measures of log consumption and consumption growth because these are suggested by academic research as being 
related to ER. None of these variables, it turns out, have much explanatory power for investor expectations. While these variables sometimes have statistically significant univariate correlations with investor expectations, they are nearly always eliminated when we control for returns and the price level. In Panel B we show representative results, in which we include 12-month earnings growth, the unemployment rate, and the risk-free interest rate. Only in the case of earnings growth do any of these variables consistently play any role in explaining investor expectations. When we include the price level and the past stock market return, these variables again become insignificant.

These results are broadly consistent with a great deal of evidence that has accumulated in finance over the last 25 years. A substantial share of investors, including individuals, CFOs, and professional investors hold extrapolative expectations. When stock prices are high, and when they have been rising, investors are optimistic about future market returns. These results decisively reject the view that survey measures of investor expectations are meaningless noise: this is both because of the high correlations of expectations across data sources and because of the highly predictable structure of expectations. In the remainder of the paper, we compare our measures of expectations with measures of ER derived from consumption-based models, and seek to provide a consistent account of the evidence.

\section{How Expectations of Returns and ER predict future returns}

Ever since Robert Shiller's (1981) path-breaking work on excess volatility of stock prices under the assumption of constant expected returns, financial economists have sought to reconcile stock market volatility with efficient markets theory. The leading approach has been to construct theoretical models in which required returns are variable in a way that explains the volatility of market prices, and to evaluate empirical measures of ER suggested by these models. We study three measures of expected 
returns suggested by this research: the dividend price ratio, surplus consumption from Campbell and Cochrane (1999), and the consumption wealth ratio from Lettau and Ludvigson (2001).,9

The starting point of this research is the behavior of the log price dividend ratio. As first pointed out by Campbell and Shiller (1988), Cochrane (1992), and Campbell and Ammer (1993), and recently summarized by Cochrane (2011), most of the variation in price dividend ratios describes variation in expected future returns rather than future dividend growth. In other words, in the decomposition of the $\log$ dividend price ratio $d p$,

$$
\operatorname{var}\left(d p_{t}\right) \approx \operatorname{cov}\left[d p_{t}, \sum_{j=1}^{k} \rho^{j-1} r_{t+j}\right]-\operatorname{cov}\left[d p_{t}, \sum_{j=1}^{k} \rho^{j-1} \Delta d_{t+j}\right]-\rho^{k} \operatorname{cov}\left(d p_{t}, d p_{t+k}\right)
$$

all of the variation in dividend-price ratios is explained by the first term. This is because, as shown by Cochrane (2008), the dividend-price ratio does not forecast changes in future dividend growth $\Delta d$. Campbell and Shiller (1989) show that there is little evidence that changes in the dividend-price ratio forecast changes in observable risk. Equation (3) is essentially an accounting identity from the viewpoint of the econometrician. In a representative agent rational expectations models, however, time-series variation in expected returns in (3) must be the same as time-series variation in expectations of returns.

To explain variation in the expected returns implied by changes in the dividend price ratio, researchers have put forth rational expectations models in which investors' required market returns fluctuate enough to match the data. These models come in three broad flavors: habit formation models in the spirit of Campbell and Cochrane (1999) that focus on the variation in investor risk aversion; long-run risk models in the spirit of Bansal and Yaron (2004) in which investors' perception of the quantity of

\footnotetext{
${ }^{8}$ We have also studied, but do not report here, a measure of ER derived from the Bansal and Yaron (2004) long-run risks model. Dana Kiku kindly provided us with a measure of expected returns from Bansal, Kiku, and Yaron (2011). Time-series variation in their measure is closely related to the dividend yield (and thus negatively correlated with most measures of survey expectations), and so we do not lose much by focusing on the dividend yield instead. We exclude this material from the paper because, although we obtain similar results as for the dividend price ratio, the data are only available annually.

${ }^{9}$ Also related, but not studied here, are models of time-varying rare disasters. See Barro (2006), Berkman, Jacobsen and Lee (2010) and Wachter (2012).
} 
long-run risk drives variation in discount rates, and so-called rare disaster models that capture timevarying estimates of disaster probability (Barro (2006), Berkman, Jacobsen and Lee (2010) and Wachter (2012)). Taking the dividend-price ratio as a proxy for ER, these models are often calibrated so as to match the time-series variation in this ratio.

We pay particular attention to the Campbell and Cochrane habit formation model, in part because of its prominence in the literature, and in part because this model suggests an empirically implementable proxy for ER. In Campbell and Cochrane, investor utility is defined relative to "habit", which is essentially a moving average of past consumption. When past consumption has been high, risk aversion falls and prices are high. As shown in Cochrane (2011), the surplus consumption ratio, computed using aggregate data on nondurable consumption, closely matches time-series variation in the price dividend ratio in recent decades.

We also study the consumption wealth ratio of Lettau and Ludvigson (2001). This variable is best understood as reflecting consumption behavior under the permanent income hypothesis, with timeseries variation in required returns (where this variation comes perhaps from habit formation models or elsewhere). If prices are high because required returns are low (rather than dividend growth being high), then consumption will rise only modestly under the permanent income hypothesis, and the consumptionwealth ratio must be low. In an endowment economy the role of consumption is analogous to that of dividends. According to Lettau and Ludvigson, "when the consumption aggregate wealth ratio is high, agents must be expecting either high returns on the market portfolio in the future or low consumption growth rates. Thus, consumption may be thought as the dividend paid from aggregate wealth." Lettau and Ludvigson do not take a position on what drives the underlying variation in expected returns, only 
that whatever is the driver, consumers understand the variation and adjust their consumption accordingly. ${ }^{10}$

Panel C of Table 1 summarizes the ER measures. We compute the log dividend yield based on CRSP value-weighted returns. Surplus consumption is computed following Campbell and Cochrane (1999) and using code provided on John Cochrane's website. We obtain cay from Martin Lettau's website.

\section{Correlations between expectations of returns and ER}

If expectations of returns are measured without noise, then models of ER predict a perfect positive correlation between investor expectations and ER. If expectations and ER are measured in the same units, the regression coefficient in a regression of expectations on ER should be exactly one. ${ }^{11}$

Table 4 shows the pairwise correlation between each measure of expectations of returns and ER. The various survey measures of expectations are available for different periods of time and at different frequencies, so the number of observations used to estimate each correlation varies.

The time-series correlation between Gallup expectations and $\log (\mathrm{D} / \mathrm{P})$ is $-0.33(\mathrm{p}$-value $=0.00)$. As suggested by the regressions in Table 2, Gallup expectations are even more strongly negatively correlated with 12-month changes in $\log (\mathrm{D} / \mathrm{P})$ (not tabulated) - the correlation is -0.57 , reflecting the role of recent returns in shaping expectations.

The second set of rows in Table 4 shows that expectations are even more strongly negatively correlated with minus the surplus consumption ratio (-0.48 correlation with Gallup and -0.53 with Graham-Harvey) The correlations between expectations of returns and the consumption wealth ratio,

\footnotetext{
${ }^{10}$ Other authors have questioned whether this assumption is reasonable. See for example Brennan and Xia (2002).

${ }^{11}$ If $E R$ and expectations are in the same units then a regression of Expectations $s_{t}=a+b E R_{t}+u_{t}$ should yield coefficients $a=0$, $b=1$, and an R-squared of one. We do not test this hypothesis here directly, because neither expectations nor ER are directly in units of expected one-year stock returns.
} 
cay, are more mixed, as can be seen in the bottom line of the table. Gallup, Graham-Harvey, and

Michigan expectations are uncorrelated with cay; Shiller expectations are positively correlated with cay; while American Institute, and Investors' Intelligence are negatively correlated with cay. Keep in mind that the null hypothesis is that expectations are perfectly positively correlated with ER. ${ }^{12}$ In addition, it turns out that the level of expectations is strongly negatively correlated with 12-month changes in cay.

The evidence in this subsection raises a significant puzzle. We have argued in earlier sections based on the consistency of survey expectations across surveys, their alignment with mutual fund flows, and their extrapolative structure - that survey measures of expectations in fact reflect the true beliefs of many investors about future returns. And theory suggests that survey expectations should be strongly positively correlated with ER. To the extent that either expectations or true ER are measured with noise, the correlation is biased towards zero. But we have now shown that these measures of expectations are if anything negatively correlated with measures of ER used by financial economists. If surveys indeed measure expectations of broad classes of investors, then what is measured by these computations of expected returns, which after all are indirect?

\section{Forecasting regressions}

A critical property of ER measures is that they actually forecast future returns, even if they lack explanatory power at short horizons. ${ }^{13}$ In this subsection, we examine the relationship between expectations of returns, ER, and realized stock returns.

Table 5 shows the results of time-series regressions of the form:

\footnotetext{
12 Although there is not much correlation if both cay and expectations are measured in levels, the correlation is strongly negative when we examine the correlation between expectations and 12-month changes in cay (not tabulated).

${ }^{13}$ See Ferson, Sarkissian and Simin (2003); Stambaugh (2000); Welch and Goyal (2008); Campbell and Yogo (2006); Campbell and Thompson (2008) and Lewellen and Shanken (2002) for a discussion of the time-series properties and performance of stock market return predictors.
} 


$$
R_{t+k}^{x}=a+b X_{t}+u_{t+k}
$$

where $R^{x}$ denotes the $k$-month excess return, i.e., cumulative return on the CRSP value weighted stock market net of the $k$-period compounded risk free rate, and $X$ is a predictor variable. ${ }^{14}$ We study the forecasting power for 12 - and 36-month forward excess returns. $t$-statistics for $k$-period return regressions are based on Newey and West (1984), using 1.5k lags.

We begin with the null hypothesis: If reported expectations measure true expected returns and are measured in the same units as ER, then expectations should forecast future returns with a coefficient of one. That is, if $X_{t}=\mathrm{E}_{\mathrm{t}}\left[R_{t+k}\right]$ then under a rational expectations null hypothesis, the coefficient $a$ in equation (4) is 0 and $b=1$. Moreover, expectations should subsume all information in statistical predictors of future stock market returns. This means that no additional forecasting variables should exhibit any additional power for forecasting returns.

To interpret the regression coefficients, we use the rescaled versions of expectations that are in the same units as stock returns. Since all rescaling is linear, this has no impact on the $t$-statistics or $R$ squared in any of the regressions, but does allow us to test whether $b=1$ in equation (4).

Panel A shows that Gallup survey return expectations negatively forecast future stock returns. The coefficient on survey expectations is -1.99 . This is in contrast to the dividend yield (column (7)) and other measures of ER, which are positively related to subsequent returns over the sample period.

In all of the univariate specifications, the explanatory power is weak, with $R$-squareds ranging from 0.02 (column (3)) to 0.34 (column (6)). Although the $t$-statistics appear to be low, we are interested in the null hypothesis that the coefficient on expectations of returns is equal to one. We can reject this null with confidence for each of the six measures of expectations. In the case of Gallup, for example, we

\footnotetext{
14 Technically, we think of the surveys as asking investors about expected nominal stock returns, although perhaps "optimistic" can be interpreted as optimistic relative to the risk-free return. We have repeated the return tests using a riskfree rate control with virtually identical results (not tabulated)
} 
can reject the null with a $p$-value of 0.04 . In the case of Graham-Harvey, the $p$-value is 0.00 . The results of these hypothesis tests are shown for all six measures of expectations at the bottom of Panel A.

Columns (9)-(14) show that the forecasting power of survey expectations is partly, but not fully, accounted for by its correlation with the dividend yield, although the magnitude varies depending on which measure of expectations we use. That is, when prices are high, both ER and realized future returns are low, but expectations are high. This result also obtains if we proxy for the price level using the log of the inflation adjusted S\&P 500 index (not tabulated).

Panel B shows that the forecasting results, which are quite weak at a 12-month horizon, tend to strengthen when we study 36-month returns. Note that here we exclude the Michigan data, because of insufficient observations to correctly compute standard errors. ${ }^{15}$

The results of this subsection in some ways deepen the puzzle identified earlier. On the one hand, measures of ER positively forecast realized returns, consistent with rational expectations models with changing required returns. On the other hand, survey measures of expectations negatively forecast realized returns, consistent with behavioral models in which investors extrapolate and are most optimistic at the top, when future returns are actually low. The evidence on the extrapolative structure of expectations is supportive of this interpretation as well. But this leaves us with the question: if measures of ER do not actually capture expectations of returns, then how can they forecast realized returns? We suggest a possible answer in the next section.

\section{A Calibration Exercise}

We are unable to reconcile our evidence with conventional representative agent asset pricing models in which investors' time-varying discount rate drives variation in stock prices. Equilibrium logic

\footnotetext{
${ }^{15}$ The OLS coefficients are strongly negative (the coefficient on Michigan is -0.12 with an OLS t-statistic of -4.16 and Rsquared of 0.46.) but not reported in the table. There are insufficient observations to compute Newey-West standard errors in the same manner as for the other regressions in Panel B.
} 
suggests that for investor expectations to negatively forecast future stock returns, there must be multiple classes of investors.

We start by specifying a simple model in which one group of investors behaves in a way that parallels the structure of expectations we observe in the data. In such a model, we can also compute some proxies for ER that previous research has identified. We can then ask under what circumstances the model can explain the available evidence, including 1) the negative correlation between model ER and expectations of returns, 2) the positive forecasting power of constructed ER for realized returns, and 3) the negative forecasting power of investor expectations for realized returns.

To construct the model, we follow (actually simplify) Cutler, Poterba, and Summers (1990b) and consider a market with two types of traders. The first type, introduced by DeLong et al. (1990b), is positive feedback traders whose beliefs and trading are shaped by prices and past returns. The second type is fundamental traders who accommodate the feedback traders' demand by buying stocks when prices are high relative to fundamentals, and selling stocks when prices are low relative to fundamentals. These fundamental traders can perhaps be rational accommodators, who are willing to buy stocks when extrapolators sell them, but have a limited risk bearing capacity and thus require a return premium (DeLong et al 1990a). ${ }^{16}$ The aggregate quantity of risk held by all investors in the model is constant, but the fundamental traders hold a time-varying amount of risk because of their accommodation of extrapolative trader demand (although their risk tolerance does not need to change over time as in many representative agent models). The model has the advantage of being perhaps the simplest behavioral model; and one constructed before most rational accounts of time varying expected returns had been articulated.

\footnotetext{
${ }^{16}$ Interpreting the fundamental traders as "reduced form rational" is not entirely straightforward. In some behavioral models such as DeLong et al (1990b), the fundamental traders can jump on the bandwagon and destabilize prices. In the model here, however, they always exert a stabilizing influence on prices.
} 


\section{Setup and Discussion}

There is a single risky asset in net supply of $q$. The asset has a terminal value $f$ but does not pay interim dividends. Every period $t$, news about the fundamentals is revealed according to the random walk:

$$
f_{t}=f_{t-1}+z_{t}
$$

In (5), $z_{t}$ is i.i.d with variance $\sigma^{2}$. Demand of the fundamental traders $s_{f t}$ is given by

$$
s_{f, t}=\beta\left(p_{t}-\alpha_{1} f_{t}-\alpha_{2} f_{t-1}\right)
$$

where $p$ denotes the $\log$ price, $f_{t}$ the $\log$ fundamental perceived at time $t$, and $\beta<0$. The magnitude of $\beta$ fixes the weight (or relative wealth) of fundamental traders in the economy. Fundamental traders buy when prices are low relative to fundamental value, and sell when prices are high. For simplicity, we fix $\alpha_{1}+\alpha_{2}=1$, meaning that their demand is proportional to the price-to-fundamental ratio, with fundamentals being observed with a lag. Allowing non-zero $\alpha_{2}$ has the effect of making fundamental traders bet slowly against mispricing, and thus introduces persistence in the price to fundamental ratio, consistent with the data in which price-dividend ratios are highly persistent. When returns are normally distributed, equation (6) is close to the demand curve that would obtain for a perfectly rational constant absolute risk aversion investor.

Demand of the positive feedback traders $s_{p t}$ is directly motivated by our data. In Section 3 and Table 3, we showed that expectations were positively related to both past returns and the current price level. We thus specify

$$
s_{p, t}=\gamma p_{t}+\delta\left(p_{t}-p_{t-1}\right)
$$

where $\gamma$ and $\delta$ are both positive. In describing positive feedback trader demand, we have also experimented with different specifications in which the $\gamma$ applies to $p$ - $f$ instead of $p$ directly. For $\gamma=0$, the demand of the positive feedback traders depends only on past returns, as in the original CPS model. It is 
also possible to add further lags of returns to equation (7), but this complicates the algebra without changing the central intuitions.

To solve the model, we impose market clearing:

$$
\gamma p_{t}+\delta\left(p_{t}-p_{t-1}\right)+\beta\left(p_{t}-\alpha_{1} f_{t}-\alpha_{2} f_{t-1}\right)=q
$$

From expression (8), we can write prices as a function of past prices and fundamentals:

$$
p_{t}=\theta+\frac{1}{\beta+\gamma+\delta}\left[\delta p_{t-1}+\beta\left(f_{t-1}+\left(1-\alpha_{2}\right) z_{t}\right)\right]
$$

where $\theta$ is the constant $q /(\beta+\gamma+\delta)$. If $\left|\frac{\delta}{\beta+\gamma+\delta}\right|<1$, the fundamental traders have sufficient riskbearing capacity to counter the potentially unstable beliefs of the positive feedback traders.

Rearranging terms in the above, we can write down the price to fundamental ratio as a function of past prices and fundamentals:

$$
p_{t}-f_{t}=\frac{\delta}{\beta+\gamma+\delta} p_{t-1}-\frac{\gamma+\delta}{\beta+\gamma+\delta} f_{t-1}-\frac{\alpha_{2} \beta+\gamma+\delta}{\beta+\gamma+\delta} z_{t}+\theta
$$

Equations (9) and (10) show how prices and price-fundamental ratios respond to fundamental news $z_{t}$. If we assume $\alpha_{2} \beta+\gamma+\delta>0$ and $\beta+\gamma+\delta<0$ then $p_{\mathrm{t}}-f_{\mathrm{t}}$ increases with $z_{t}$. To see this, consider what happens following a positive shock $z_{t}$. The equilibrium price $p_{t}$ has to change by $\frac{\left(1-\alpha_{2}\right) \beta}{\beta+\gamma+\delta} z_{t}$ for the market to clear, and $\frac{\left(1-\alpha_{2}\right) \beta}{\beta+\gamma+\delta}$ is greater than 1 as long as $\gamma+\delta$ are neither too small (absolute value of $\beta$ $+\gamma+\delta$ smaller than $\left.\alpha_{1} \beta\right)$ nor too large $(\beta+\gamma+\delta<0)$. Intuitively, a good fundamental shock increases fundamental traders' demand and therefore the price, which in turn leads to an increase in the feedback traders' demand. However, since the asset is in fixed net supply, it is impossible for both types of traders' demand to increase in the same direction. If $\beta+\gamma+\delta>0$, then positive feedback traders are more sensitive to price changes than fundamental traders. In this case, the equilibrium price must end 
up lower so that feedback traders' demand eventually decreases. On the other hand, if $\beta+\gamma+\delta<0$, then fundamental traders' demand is more sensitive to price. In this case, the equilibrium price must end up higher so that fundamental traders' demand decreases. If $\gamma+\delta$ is too small, or feedback traders are not very sensitive to price changes, then the price response to the fundamental shock will also be small.

To work out how the demand of positive feedback traders responds to news about fundamentals, we write their demand $s_{p, t}$ as a function of $z_{t}$ and past values of prices and fundamentals:

$$
\begin{aligned}
s_{p, t} & =(\gamma+\delta) p_{t}-\delta p_{t-1} \\
& =\frac{-\beta \delta}{\beta+\gamma+\delta} p_{t-1}+\frac{\beta(\gamma+\delta)}{\beta+\gamma+\delta} f_{t-1}+\frac{\beta\left(1-\alpha_{2}\right)(\gamma+\delta)}{\beta+\gamma+\delta} z_{t}+(\gamma+\delta) \theta .
\end{aligned}
$$

When $\beta+\gamma+\delta<0$, positive feedback trader's demand rises with fundamental shock. This follows from our earlier intuition that the equilibrium price $p_{t}$ rises following a positive shock to fundamentals.

Finally, we can use the model to understand the relationship between fundamental news, the price-to-fundamental ratio $p_{t}-f_{t}$, and future returns $p_{t+1}-p_{t}$. Returns are given by

$$
p_{t}-p_{t-1}=\frac{1}{\beta+\gamma+\delta}\left[\delta\left(p_{t-1}-p_{t-2}\right)+\beta\left(\alpha_{1} z_{t}+\alpha_{2} z_{t-1}\right)\right] .
$$

Consider the path of prices following a shock $z_{t}$. Using (9) and (12), future returns $p_{t+1}-p_{\mathrm{t}}$ respond to $z_{t}$ according to

$$
\frac{d\left(p_{t+1}-p_{t}\right)}{d z_{t}}=\frac{\beta}{\beta+\gamma+\delta}\left(\alpha_{2}+\frac{\delta\left(1-\alpha_{2}\right)}{\beta+\gamma+\delta}\right) .
$$

For $\beta+\gamma+\delta<0$, the first term is positive. The entire expression is then negative when $\alpha_{2}$ is small or $\delta$ is large (for $\alpha_{2}(\beta+\gamma)+\delta>0$ ). Intuitively, if the fundamental traders are responsive enough to price changes, they eventually push price back to near-fundamental levels, leading to mean reversion.

\section{Calibration}


To get a sense of how the model specified above might allow us to reconcile the negative correlation between ER and expectations of returns, we consider a simple exercise in which we simulate returns using functional forms of feedback trader expectations based on our data. We interpret the fundamental $f_{t}$ as being analogous to a dividend on the stock market, in which case $p_{t}-f_{t}$ is the log pricedividend ratio.

We first specify demand of the positive feedback traders. Following the coefficients in the first column of Table 3, we write

$$
s_{p, t}=0.17 p_{t}+0.34\left(p_{t}-p_{t-1}\right) .
$$

Here the absolute scale of the coefficients is arbitrary (we can simply double the number of positive feedback traders or cut them in half), but we use Table 3 to pin down the relative magnitudes of the $\delta$ and $\gamma$ coefficients.

For the fundamental traders' demand, as an example we choose the coefficients in Cutler, Poterba and Summers, i.e.,

$$
s_{f, t}=-1\left(p_{t}-0.75 f_{t}-0.25 f_{t-1}\right) \text {. }
$$

Fundamental traders bet on the fundamental, but observe it with a slight lag. Note that we have chosen $\beta=-1$, which means that the fundamental traders have the same weight in the model as the positive feedback traders.

We simulate 5000 paths of 100 years of stock market returns. In each simulation, we throw out the first 50 years of simulated returns, and study the relationship between prices, dividend yields, the current fundamental $f_{t}$, and future stock market returns for the last 50 years of the sample. The idea is to get as close as possible to our empirical specification in Table 5, where we have a maximum of 50-years of expectations data and returns.

For each simulation, we run regressions of the form 


$$
p_{t+k}-p_{t}=a+b X_{t}+u_{t+k}
$$

where the left-hand side is the log return, and $X$ denotes a predictor variable drawn from our data. For each simulation, we store the coefficient estimate $b$ and the $R$-squared from this regression, which we summarize in Table 6. As predictors, we use $f-p$ (analogous to the dividend-price ratio), innovations in the fundamental $z$, the fundamental $f$, and the difference between the fundamental and its moving average (analogous to a "surplus fundamental"). The idea is to approximate the predictors that have been emphasized in the predictability literature. Some caution is warranted in interpreting these predictors, however, since we have not worked out a full model with consumption. ${ }^{17}$ Notwithstanding, it is straightforward to see that, if dividends are correlated with aggregate consumption, then changes in consumption or dividends can be related to future returns.

Table 6 shows that we can match many of the facts developed so far. Specifically, in this model, expectations of one group of traders are extrapolative. These expectations are negatively correlated with measured ER and negatively forecast future returns, while measured ER $(f-p$ in our simulated regressions) positively forecasts future returns. Critically, this is so even though measured ER has nothing to do with changes in risk aversion as contemplated by rational expectations models.

The evidence thus raises a possibility that might account for all the evidence, namely that financial markets are governed by a behavioral model including positive feedback traders exhibiting extrapolative expectations, as well as accommodating fundamentalists. In such a model, ER accurately reflects the fundamental traders' required returns, but equilibrium prices are far from rational.

\section{Who is on the Other Side?}

\footnotetext{
${ }^{17}$ This is especially true for the "surplus fundamental", in which we are trying to approximate surplus consumption. Our model does not involve consumption; notwithstanding, it is straightforward to see that if dividends are correlated with aggregate consumption, then changes in consumption or dividends can be related to future returns. The results in Table 6 suggest this approach could be fruitful.
} 
While the surveys document the ubiquity of extrapolative investors, in equilibrium these investors' demands must be accommodated, thereby raising the question of who is on the other side. Who are the fundamentalists? While a full investigation of this question is constrained by data on stock market positions, previous research in corporate finance that suggests firms play an important role in accommodating shifts in investor demand. Baker and Wurgler (2000) suggest that firms issue equity when overall market prices are high, and Frazzini and Lamont (2008) suggest that firms may issue stock in response to retail mutual fund flows. And, it is well known that firms tend to issue equity following periods when the market has performed well (Shultz 2002; Baker and Xuan 2009).

Figure 6 plots the Gallup series alongside the number of IPOs in that month, obtained from Jeff Wurgler's website. There is a strong positive correlation $(\rho=0.60)$ between the two time series, consistent with the idea that equity issuance plays a significant accommodative role. That is, the fundamentalists in the CPS model, in part, are firms. Table 7 shows the corresponding specifications for the full set of survey, where we regress the number of IPOs in month $t$ on survey expectations in the same month. For all but one of the surveys (Shiller), the correlation is positive, and for all but two the correlation is strongly statistically significant. In the last column of the table, we further show the strong positive correlation between mutual fund inflows and the number of IPOs. This evidence is tentative, but it points strongly in the direction of a behavioral model in which firms are among the rational investors accommodating swings in demand by extrapolative traders.

\section{Conclusions}

Much of modern asset pricing seeks to explain changes in stock market valuations using theories of investors' time-varying required returns. Although researchers have achieved considerable progress in developing proxies for ER, an important but often overlooked test of these theories is whether investors' expectations line up with these proxies. In this paper, we show that they do not. 
At a minimum, our evidence rules out rational expectations models in which changes in market valuations are driven by the required returns of a representative investor. Although prices may behave in a way that is observationally equivalent to such models, survey expectations are inconsistent with the standard model's predictions. We suggest a simple behavioral alternative, in which variation in market prices is driven by changes in demand by extrapolative investors captured in expectations data, and accommodated by fundamental, and possibly rational investors. Future models of stock market fluctuations should embrace the large fraction of investors whose expectations are extrapolative. 


\section{References}

Amronin, Gene and Steven A. Sharpe, 2008, "Expectation of Risk and Return Among Household Investors: Are their Sharpe Ratios Countercyclical?" Finance and Economics Discussion Series Working Paper, 2008-17, Federal Reserve Board, Washington DC.

Bacchetta, Philippe, Elmar Mertens, and Eric van Wincoop, 2009, "Predictability in Financial Markets: What Do Survey Expectations Tell Us?” Journal of International Money and Finance, 406-426.

Baker, Malcolm, and Jeffrey Wurgler, 2000, “The Equity Share in New Issues and Aggregate Stock Returns" Journal of Finance 55, 2219-57.

Baker, Malcolm, and Yuhai Xuan, 2009, “Under New Management: Equity Issuance and the Attribution of Past Returns," Working paper.

Bansal, Ravi, Dana Kiku and Amir Yaron, 2012, “An Empirical Evaluation of the Long-Run Risks Model for Asset Prices," Critical Finance Review 1 (1): 183-221.

Bansal, Ravi and Amir Yaron, 2004, "Risks for the Long Run: A Potential Resolution of Asset Pricing Puzzles," Journal of Finance 59 (4): 1481-1509.

Ben-David, Itzhak, John R. Graham and Campbell R. Harvey, 2010. "Managerial Miscalibration," NBER Working Papers 16215.

Barberis, Nicholas, Andrei Shleifer and Robert Vishny, 1998, “A Model of Investor Sentiment,” Journal of Financial Economics 49 (3): 307-343.

Barro, Robert J., 2006, "Rare disasters and asset markets in the twentieth century," The Quarterly Journal of Economics, 823-866.

Barsky, Robert B. and J. Bradford DeLong, 1993, “Why Does the Stock Market Fluctuate?” Quarterly Journal of Economics 108, 291-311.

Berkman, Henk, Ben Jacobsen, and John Lee, 2010, “Time-varying Rare Disaster Risk and Stock Returns," forthcoming, Journal of Financial Economics.

Brennan, Michael J. and Yihong Xia, 2005, “Tay's as Good as Cay,” Finance Research Letters 2, 1-14.

Campbell, John Y \& Ammer, John, 1993. "What Moves the Stock and Bond Markets? A Variance Decomposition for Long-Term Asset Returns," Journal of Finance 48, 3-37.

Campbell, John Y., and John H. Cochrane, 1999, "By force of habit: A consumption-based explanation of aggregate stock market behavior", Journal of Political Economy 107, 205-251.

Campbell, John Y. and Albert S. Kyle, 1993, "Smart Money, Noise Trading and Stock Price Behaviour," Review of Economic Studies 60 (1): 1-34.

Campbell, John Y. and Robert J. Shiller, 1988a, "The Dividend-Price Ratio and Expectations of Future Dividends and Discount Factors," Review of Financial Studies 1, 195-228. 
Campbell, John Y. and Robert J. Shiller, 1988b, "Stock Prices, Earnings, and Expected Dividends," Journal of Finance 43 (3): 661-676.

Campbell, John Y., and Samuel B. Thompson, 2008. "Predicting Excess Stock Returns Out of Sample: Can Anything Beat the Historical Average?," Review of Financial Studies 21, 1509-1531.

Campbell, John Y. \& Yogo, Motohiro, 2006. "Efficient tests of stock return predictability," Journal of Financial Economics 81, 27-60.

Case, Karl E., Robert J. Shiller, and Anne Thompson, 2012, "What Have They Been Thinking? Home Buyer Behavior in Hot and Cold Markets." Brookings Papers on Economic Activity.

Cecchetti, Stephen G., Pok-sang Lam and Nelson C. Mark, 2000, “Asset Pricing With Distorted Beliefs: Are Equity Returns Too Good To Be True?” American Economic Review 90 (4): 787-805.

Clarke, Roger G., and Meir Statman, 1998, "Bullish or Bearish," Financial Analysts Journal 54, 63-72.

Cochrane, John H., 1992, "Explaining the Variance of Price-Dividend Ratios," Review of Financial Studies 5, 243-80.

Cochrane, John H., 2008, "The Dog that Did Not Bark: A Defense of Return Predictability," Review of Financial Studies 21, 1533-1575.

Cochrane, John H., 2011, "Presidential Address: Discount Rates," Journal of Finance 66 (4): 10471108.

Cutler, David M., James M. Poterba, and Lawrence H. Summers, 1991, "Speculative Dynamics," Review of Economic Studies 58 (3): 529-546.

Cutler, David M., James M. Poterba, and Lawrence H. Summers, 1990, "Speculative Dynamics and the Role of Feedback Traders," American Economic Review 80 (2): 63-68.

Datta, Deepa Dhume and Wenxin Du, 2012, Nonparametric HAC Estimation for Time Series Data with Missing Observations, Working paper.

DeLong, J. Bradford, Andrei Shleifer, Lawrence H. Summers, and Robert J. Waldmann, 1990a, "Noise Trader Risk in Financial Markets," Journal of Political Economy 98, 703-738.

DeLong, J. Bradford, Andrei Shleifer, Lawrence H. Summers, and Robert J. Waldmann, 1990b, "Positive Feedback Investment Strategies and Destabilizing Rational Speculation," Journal of Finance 45 (2): 379-395.

Dominguez, Kathryn M., 1986, Are Foreign Exchange Forecasts Rational?: New Evidence from Survey Data, Economics Letters 21, 277-281.

Dominitz, Jeff, and Charles F. Manski, 2010, "Measuring and Interpreting Expectations of Equity Returns," Journal of Applied Econometrics 26, 352-370.

Ferson, Wayne E., Sergei Sarkissian and Timothy T. Simin, 2003. "Spurious Regressions in Financial Economics?," Journal of Finance 58, 1393-1414. 
Frankel, Jeffrey A. and Kenneth A. Froot, "Explaining the Demand for Dollars: International Rates of Return, and the Expectations of Chartists and Fundamentalists," in Macroeconomics, Agriculture, and the Exchange Rate, eds. Robert G. Chambers and Philip L. Paarlberg, Boulder, CO: Westview Press (1988).

Frankel, Jeffrey A. and Kenneth A. Froot., 1986. "Explaining the Demand for Dollars: International Rates of Return and the Expectations of Chartists and Fundamentalists," Economics Working Papers 8603, University of California at Berkeley.

Frankel, Jeffrey A. and Kenneth A. Froot, 1987, "Using Survey Data to Test Standard Propositions Regarding Exchange Rate Expectations," American Economic Review 77 (1): 133-153.

Fisher, Kenneth L., and Meir Statman, 2002, "Blowing Bubbles," Journal of Psychology and Financial Markets, 3, 53-65.

Frazzini, Andrea, and Owen Lamont, 2008, "Dumb Money: Mutual Fund Flows and Cross-Section of Stock Returns," Journal of Financial Economics 88, 299-322.

Froot, Kenneth A., 1989, "New Hope for the Expectations Hypothesis of the Term Structure of Interest Rates," Journal of Finance 44 (2): 283-305.

Fuster, Andreas, David Laibson and Brock Mendel, 2010, "Natural Expectations and Macroeconomic Fluctuations," Journal of Economic Perspectives 24 (4): 67-84.

Graham, John R. and Campbell R. Harvey, 1996, "Market timing ability and volatility implied in investment newsletters' asset allocation recommendations," Journal of Financial Economics 42, $397-421$.

Greenwood, Robin and Samuel G. Hanson, 2012, "Issuer Quality and Corporate Bond Returns," Working paper.

Hirshleifer, David, 2001, "Investor Psychology and Asset Pricing," Journal of Finance 56 (4): 15331597.

Hurd, Michael, Maarten van Rooij and Joachim Winter, 2009, "Stock Market Expectations of Dutch Households," De Nederlandsche Bank Working Paper No. 228.

Lakonishok, Josef, Andrei Shleifer and Robert W Vishny, 1994, "Contrarian Investment, Extrapolation, and Risk," Journal of Finance 49, 1541-78.

Lamont, Owen, 2003, Discussion of "Perspectives on Behavioral Finance: Does Irrationality Disappear with Wealth? Evidence from Expectations and Actions" by Annette Vissing-Jorgensen, NBER Macroeconomics Annual 2003, edited by Mark Gertler and Kenneth Rogoff.

Lamont, Owen, 2012, "Risk on, Risk off: Return-chasing Flows and Stock/bond Dynamics," Working paper.

Lettau, Martin and Sydney C. Ludvigson, 2005, "Expected Returns and Expected Dividend Growth," Journal of Financial Economics 76 (3): 583-626. 
Lettau, Martin and Sydney Ludvigson, 2001, "Consumption, Aggregate Wealth, and Expected Stock Returns," Journal of Finance 56 (3): 815-849.

Lewellen, Jonathan, and Jay Shanken, 2010. "A skeptical appraisal of asset pricing tests," Journal of Financial Economics 96 175-194.

Malmendier, Ulrike, and Stefan Nagel, 2011, "Depression Babies: Do Macroeconomic Experiences Affect Risk-Taking?" Quarterly Journal of Economics 126, 373-416.

Nagel, Stefan, 2012, "Macroeconomic Experiences and Expectations: A Perspective on the Great Recession," Working paper.

Newey, W. K., and K. D. West, 1987 "A Simple, Positive Semi-Definite Heteroskedasticity and Autocorrelation Consistent Covariance Matrix," Econometrica, 55(3), 703-708.

Shiller, Robert, 1981, Do stock prices move too much to be justified by subsequent changes in dividends? American Economic Review 71, 421-436.

Shiller, Robert J., 2000, "Measuring Bubble Expectations and Investor Confidence," Journal of Psychology and Financial Markets 1 (1): 49-60.

Shiller, Robert J., Kon-ya Fumiko, and Yoshiro Tsutsui, 1996, "Investor Behavior in the October 1987 Stock Market Crash: The Case of Japan,” The Journal of Japanese and International Economics.

Robert J. Shiller, Irrational Exuberance, Princeton University Press, Princeton NJ, 2000.

Schultz, Paul, 2002, "Pseudo Market Timing," Journal of Finance.

Sirri, Erik R., and Peter Tufano, 1998, “Costly Search and Mutual Fund Flows,” Journal of Finance 53, 1589-1622.

Stambaugh, Robert F., 1999, Predictive regressions, Journal of Financial Economics 54, 375-421.

Vissing-Jorgensen, Annette, 2004, "Perspectives on Behavioral Finance: Does 'Irrationality' Disappear with Wealth? Evidence from Expectations and Actions," in NBER Macroeconomics Annual, Volume 18, eds. Mark Gertler and Kenneth Rogoff, Cambridge, MA: MIT Press (2004).

Wachter, Jessica, 2012, "Can Time-varying Risk of Rare Disasters Explain Aggregate Stock Market Volatility?" forthcoming Journal of Finance.

Welch, Ivo, and Amit Goyal, 2008, "A Comprehensive Look at The Empirical Performance of Equity Premium Prediction", Review of Financial Studies 21, 1455-1508.

Yagan, Danny, 2012, “Why Do Individual Investors Chase Stock Market Returns? Evidence of Belief in Long-Run Market Momentum,” Working Paper. 


\section{Appendix: Measures of Investor Expecatations and Mutual Fund Flows}

\begin{tabular}{|c|c|c|}
\hline Survey Name & Periodicity & Detail \\
\hline $\begin{array}{l}\text { Gallup: } \\
\text { October 1996-December } 2011\end{array}$ & Monthly, with gaps & $\begin{array}{l}\text { We use three series. The longest-running series asks } \\
\text { investors whether they are "very pessimistic" } \\
\text { "pessimistic" "neutral" "optimistic" or "very } \\
\text { optimistic" about the market, we measure. This series } \\
\text { is almost complete with reporting every month, with a } \\
\text { notable gap between November } 2009 \text { and February } \\
\text { 2011. A shorter series (September } 1998 \text {-April 2003) } \\
\text { asks for a percentage expected return over the next } \\
\text { twelve months. A shorter series still (September 1998- } \\
\text { March 2000) asks for the "minimum acceptable } \\
\text { return" over the next } 12 \text { months. }\end{array}$ \\
\hline $\begin{array}{l}\text { Graham-Harvey: } \\
\text { October 2000-December } 2011\end{array}$ & Quarterly & $\begin{array}{l}\text { Sample is Chief Financial Officers of large U.S. } \\
\text { Corporations. (http://www.cfosurvey.org/) }\end{array}$ \\
\hline $\begin{array}{l}\text { American Association of } \\
\text { Individual Investors: } \\
\text { July 1987-December } 2011\end{array}$ & $\begin{array}{l}\text { Weekly; we use a monthly- } \\
\text { sampled series }\end{array}$ & $\begin{array}{l}\text { Surveyed investors claim to be "bullish," "neutral" or } \\
\text { "bearish." We measure investor expectations as } \\
\text { "bullish" minus "bearish" } \\
\text { (http://www.aaii.com/sentimentsurvey/sent_results) }\end{array}$ \\
\hline $\begin{array}{l}\text { Investor Intelligence: } \\
\text { January 1963-December } 2011\end{array}$ & $\begin{array}{l}\text { Weekly, we use a monthly- } \\
\text { sampled series }\end{array}$ & $\begin{array}{l}\text { Investment newsletters are classified as being } \\
\text { "bullish," "neutral" or "bearish." We measure investor } \\
\text { expectations as "bullish" minus "bearish" } \\
\text { (http://www.investorsintelligence.com/x/default.html) }\end{array}$ \\
\hline $\begin{array}{l}\text { Shiller Individual Investors: } \\
\text { April 1999-December } 2011\end{array}$ & $\begin{array}{l}\text { Every 6-months before July } \\
\text { 2001, after that monthly }\end{array}$ & $\begin{array}{l}\text { Sample is drawn from list of wealthy investors. } \\
\text { (http://icf.som.yale.edu/stock-market-confidence- } \\
\text { indices-united-states-one-year-index-data) }\end{array}$ \\
\hline $\begin{array}{l}\text { University of Michigan Survey } \\
\text { Research Center } \\
\text { September 2000-October } 2005\end{array}$ & Sporadic, 22 surveys in total & $\begin{array}{l}\text { We use the mean response to the question "Now, } \\
\text { thinking about a broadly diversified set of investments } \\
\text { in U.S. stocks and stock mutual funds, what is the } \\
\text { average annual percentage rate of return that you } \\
\text { would expect it to earn over the next } 2 \text { to } 3 \text { years?" }\end{array}$ \\
\hline $\begin{array}{l}\text { Mutual Fund Flows: } \\
\text { January 1984-December } 2011\end{array}$ & Monthly & $\begin{array}{l}\text { From Investment Company Institute. We scale dollar } \\
\text { flows into equity mutual funds by the size of the US } \\
\text { equity market from CRSP. } \\
\text { (http://www.ici.org/info/flows_data_2012.xls) }\end{array}$ \\
\hline
\end{tabular}


Figure 1

The Gallup Survey

The main Gallup series is computed as the fraction of investors who are bullish (optimistic or very optimistic) minus the fraction of investors who are bearish. The figure also shows a short time-series when investors reported their "minimum acceptable return" and a slightly longer time-series of their percentage "expected returns." The latter two series are marked on the right axis.

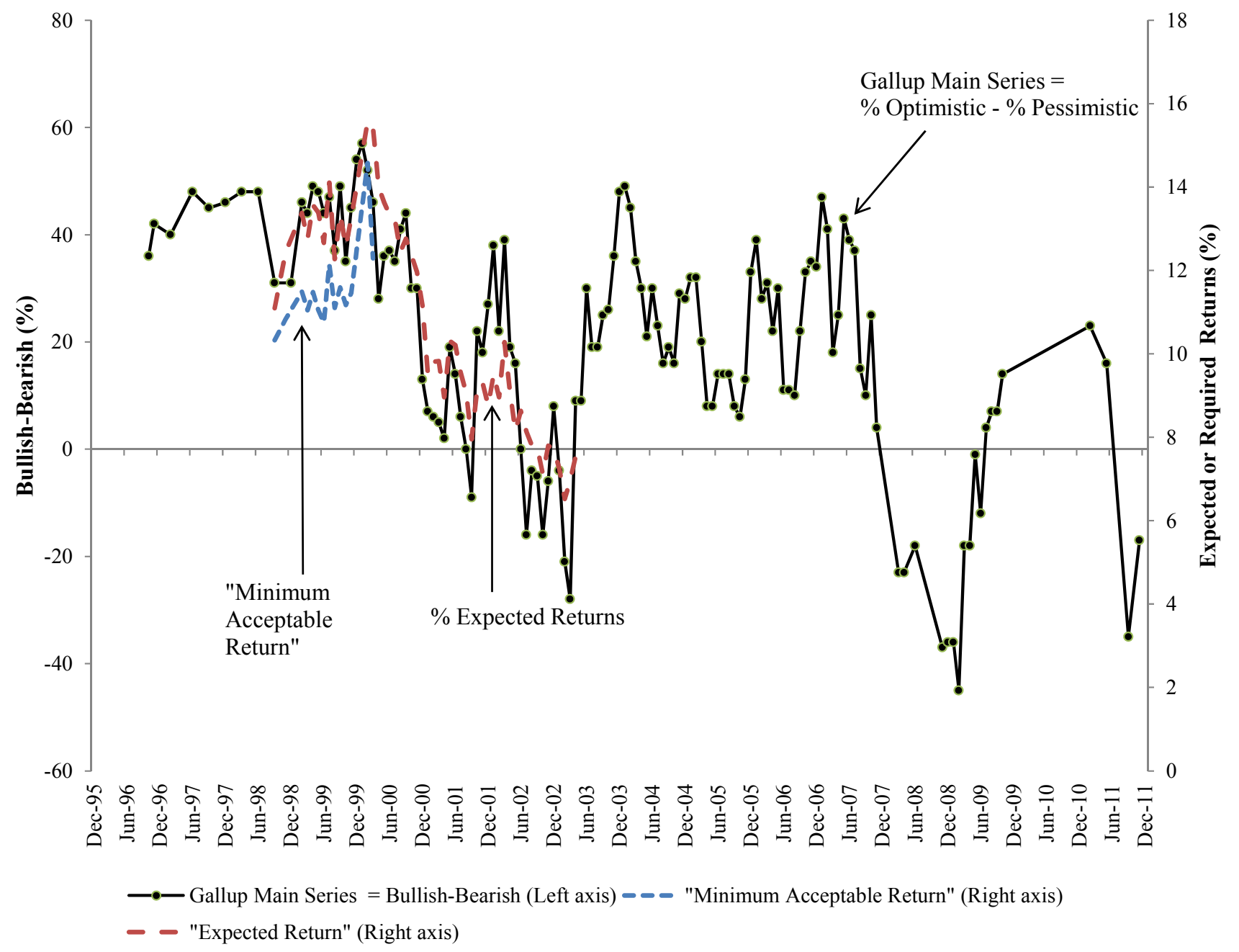


Figure 2

Comparing the Gallup Survey with Graham-Harvey CFO expectations

The main Gallup series, marked with a solid line (left axis), is computed as the fraction of investors who are bullish (optimistic or very optimistic) minus the fraction of investors who are bearish. The dashed line denotes forecasts of nominal returns made by CFOs in John Graham and Campbell Harvey's quarterly surveys (right axis).

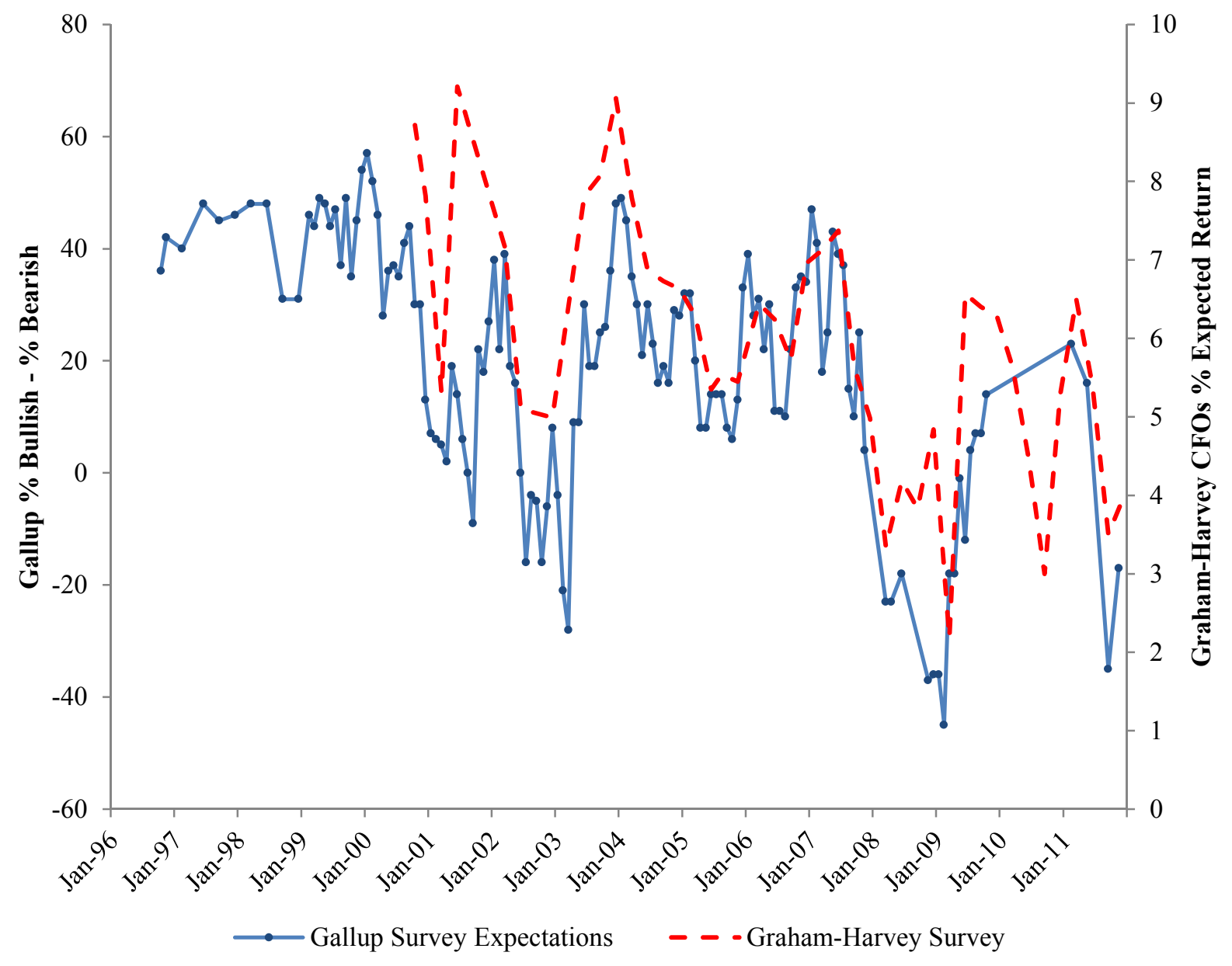


Figure 3

Comparing the Gallup Survey with American Association, Investor Intelligence, Shiller, and the Michigan Surveys

In each panel, the solid line shows the Gallup survey (left axis) and the dashed line shows the other survey.

Panel A. Gallup and American Association

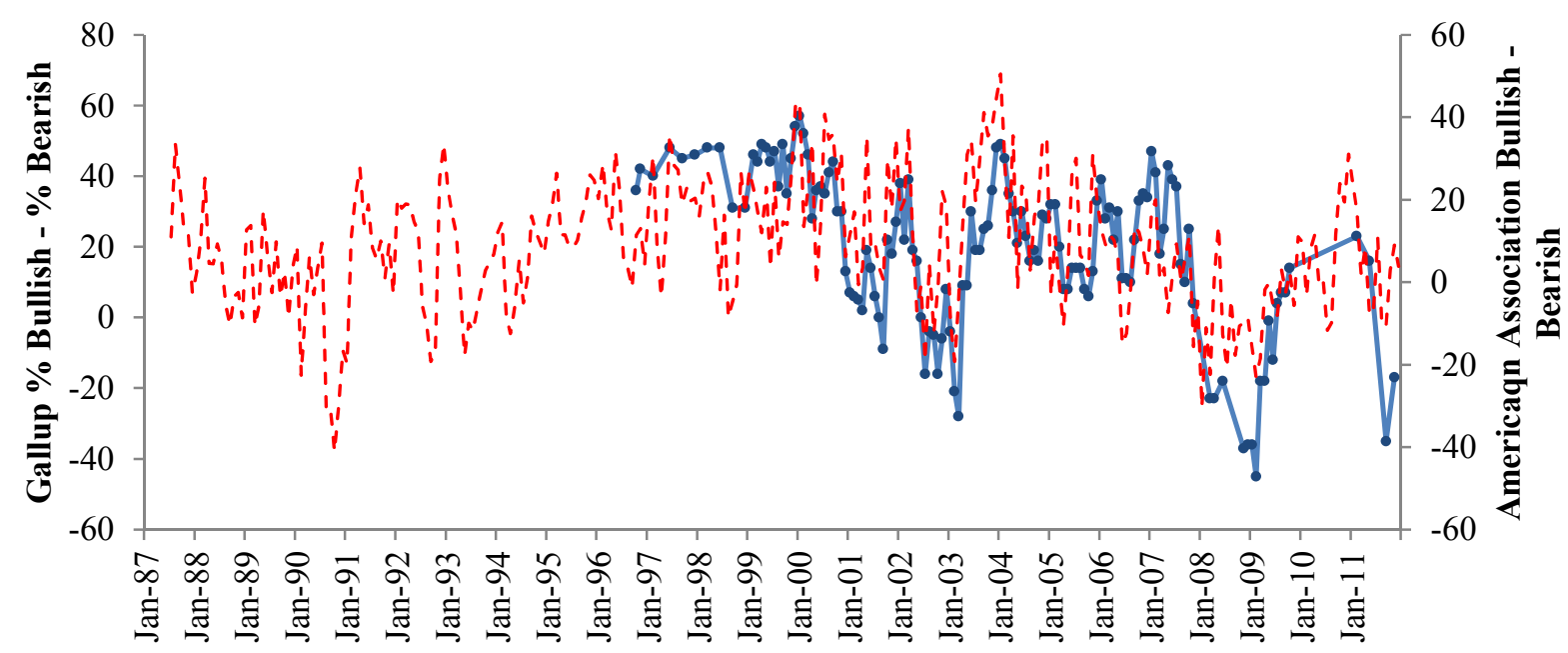

$\longrightarrow$ Gallup Survey Expectations _ - - - American Association

Panel B. Gallup and Investor Intelligence

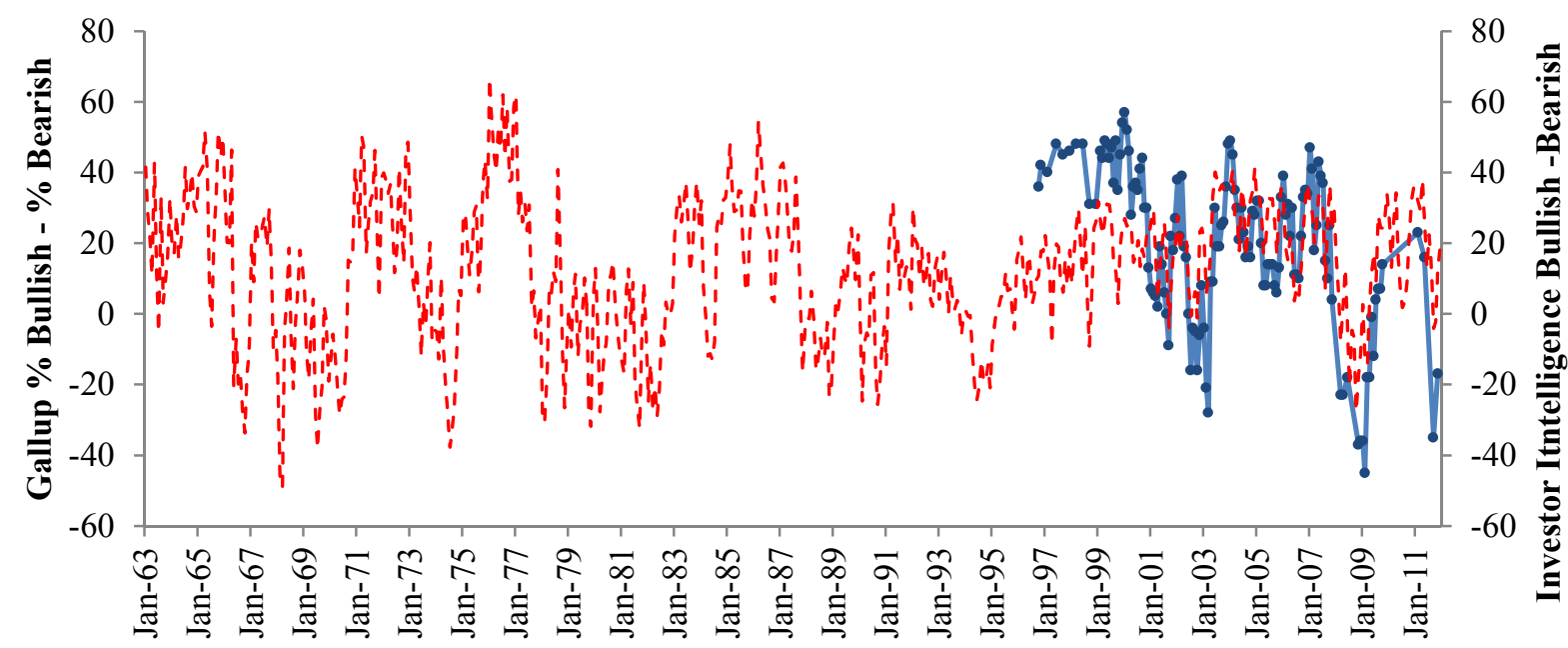

—-Gallup Survey Expectations _ _ - - - Investor Intelligence 
Figure 3 [Continued]

Comparing the Gallup Survey with American Association, Investor Intelligence, and the Shiller Survey

Panel C. Gallup and Shiller

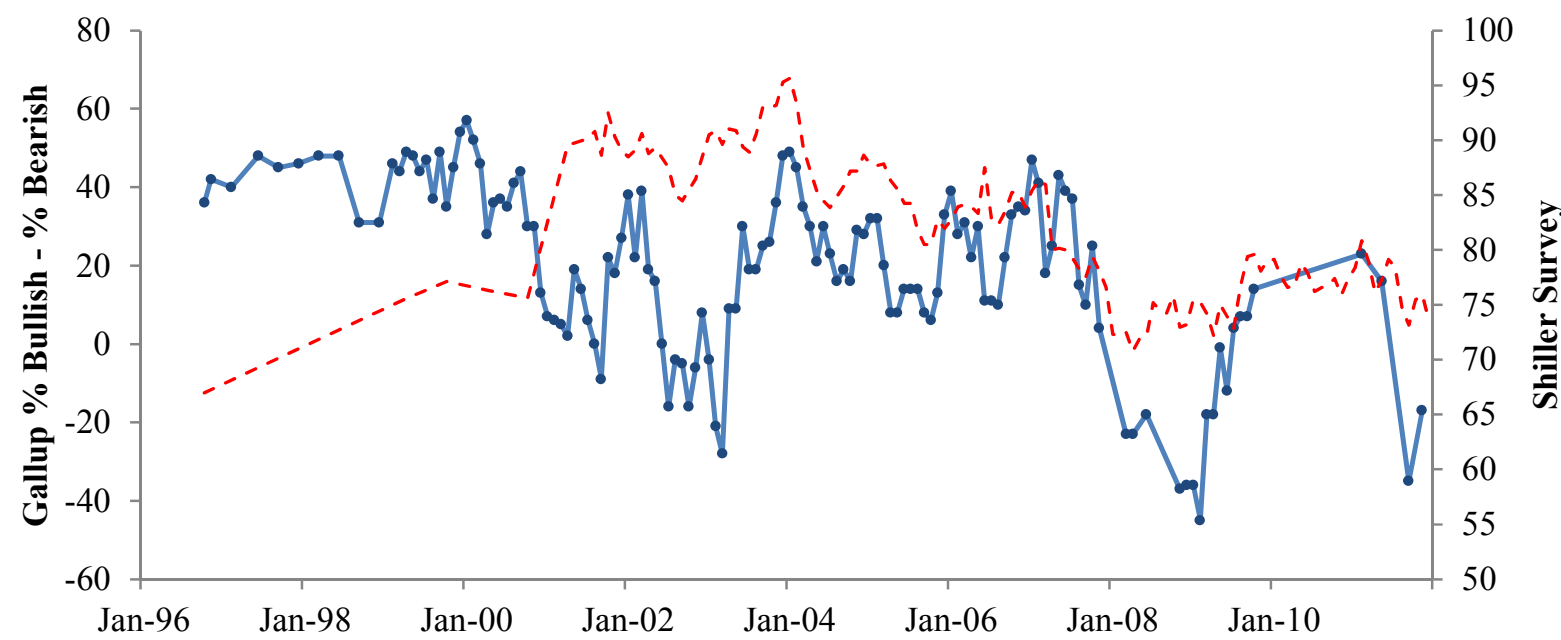

—-Gallup Survey Expectations - - - - Shiller

Panel D. Gallup and Michigan

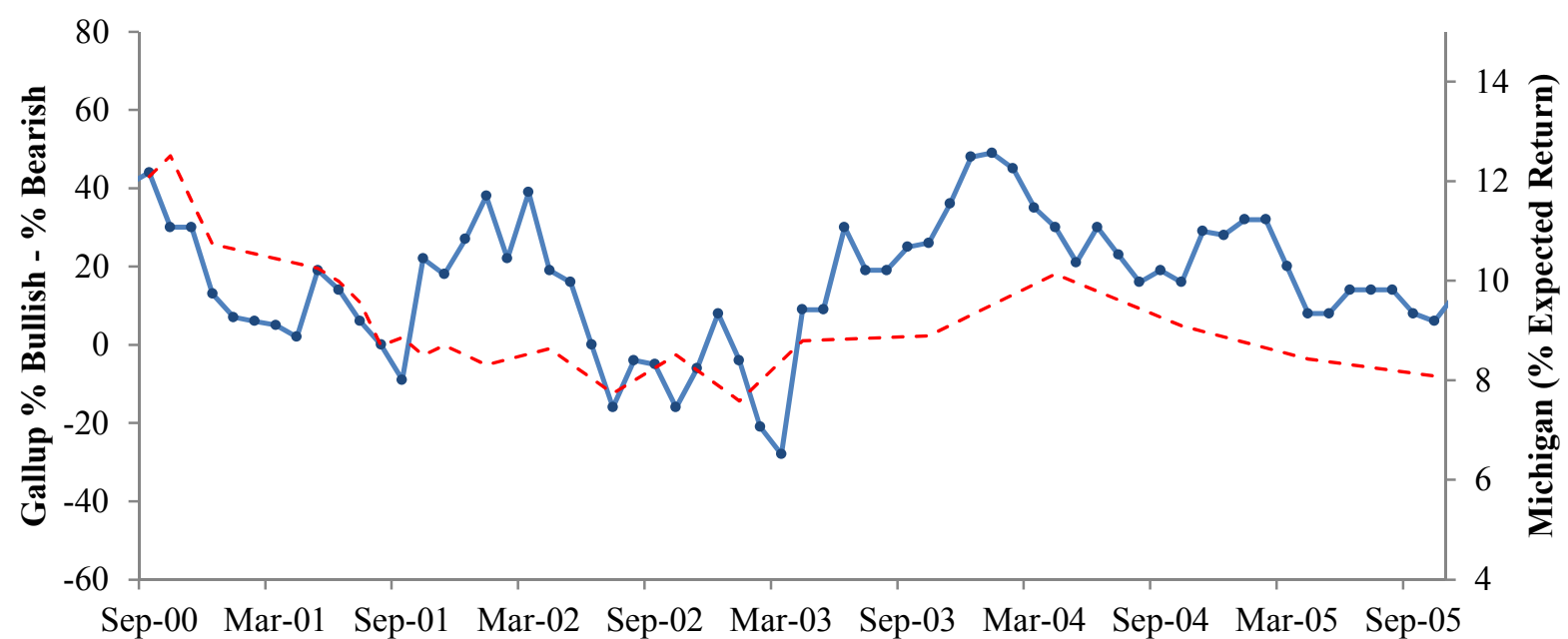

$\longrightarrow$ Gallup Survey Expectations _ - - - Michigan 
Figure 4

Comparing the Gallup Survey with Flows into Equity Mutual Funds

The solid denotes the percentage of investors who are bullish in the Gallup survey (left axis). The dashed line (right axis) is flows into mutual funds as a percentage of equity market capitalization, as reported by the Investment Company Institute.

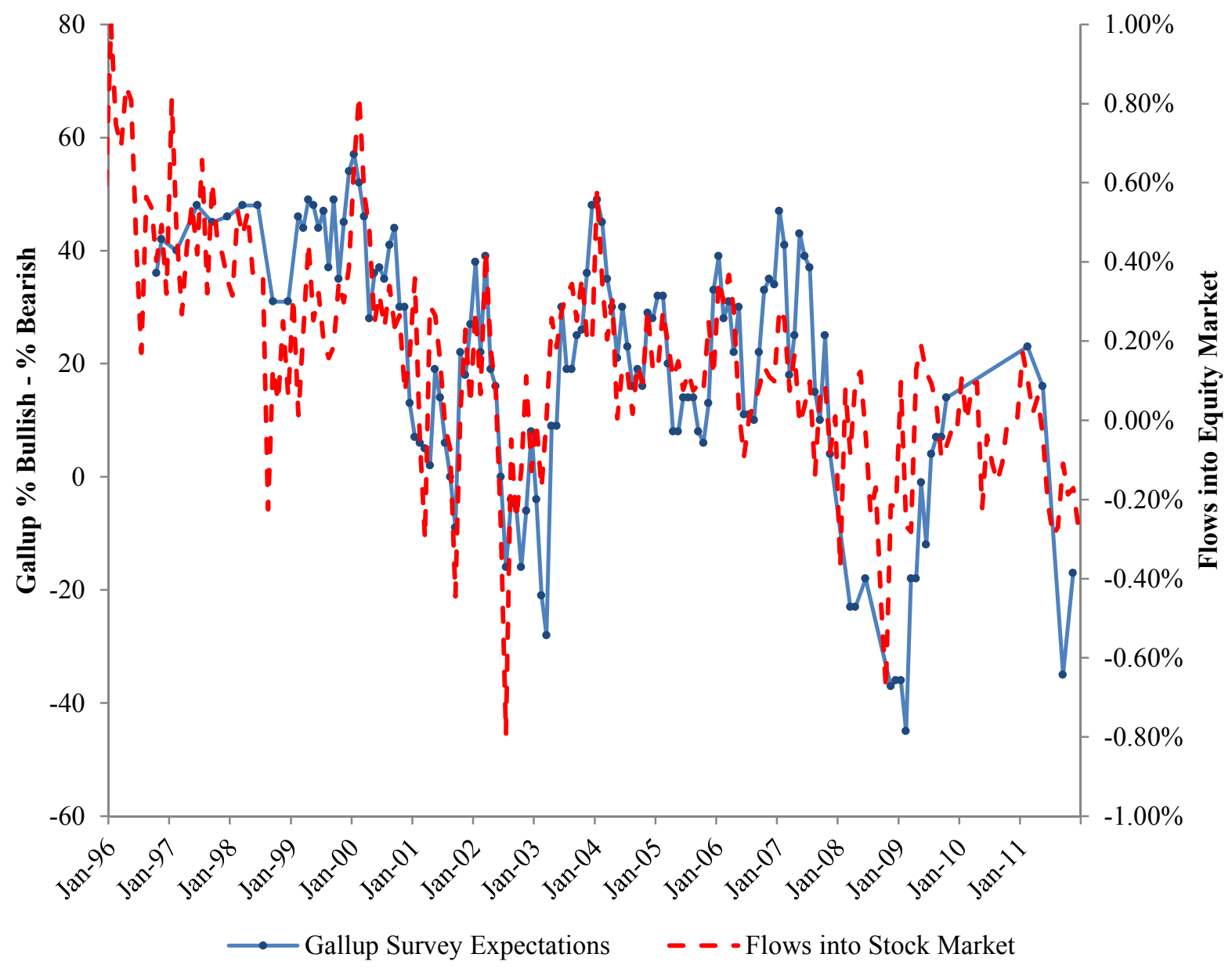


Figure 5

The Role of Past Stock Market Returns in Explaining Survey Expectations

The dashed line denotes the 12-month rolling nominal return on the CRSP VW stock index. The solid line marked with circles denotes expectations from the Gallup survey (\% optimistic - \%pessimistic).

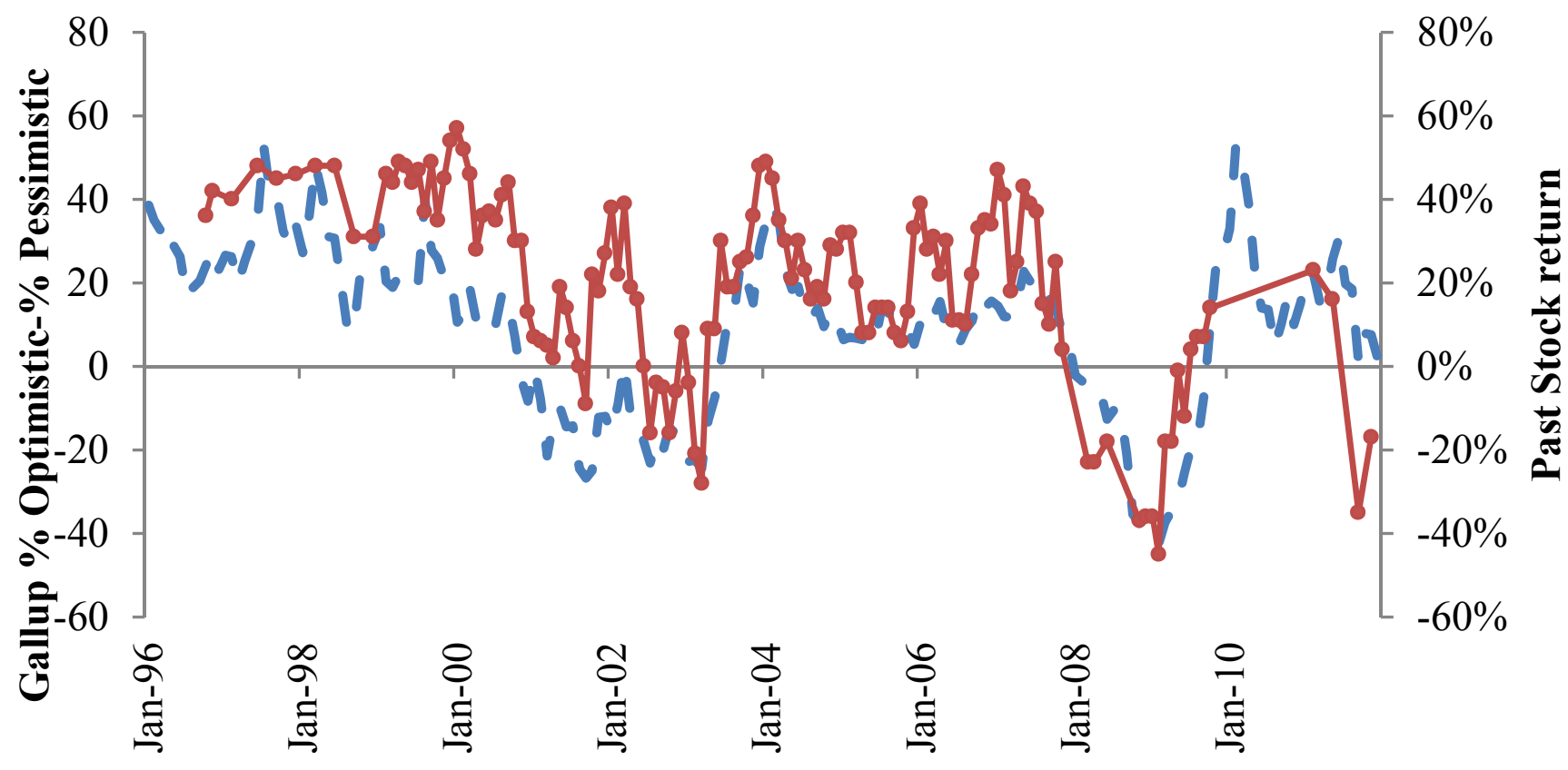

- - Lagged 12-month Returns

Gallup Survey Expectations 
Figure 6

Survey Expectations and IPO Activity

Gallup Survey Expectations and IPO activity. $(\rho=0.60)$

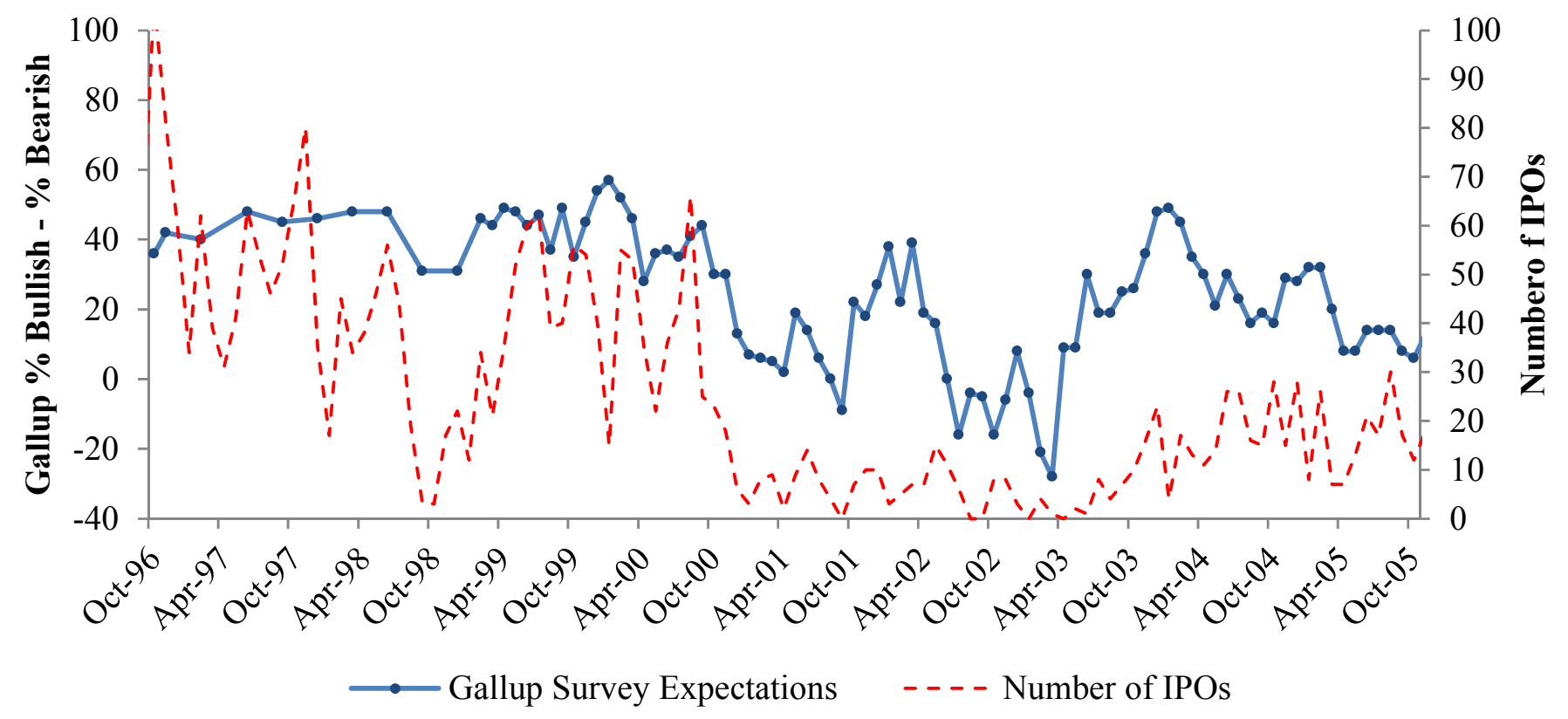


Table 1

\section{Summary Statistics}

Mean, median, standard deviation, extreme values, and the monthly autocorrelations. Gallup, American Association, and Investor Intelligence are all index values based on whether polled survey respondents claim to be optimistic or pessimistic. Graham-Harvey and Michigan are measures of the percentage expected return, and Shiller measures the fraction of surveyed investors who report positive expected returns. For GrahamHarvey, the autocorrelation is quarterly. Panel A shows measures of investor expectations. Panel B rescales the qualitative measures of investor expectations so that they can be interpreted as a percentage nominal stock return. Panel $\mathrm{C}$ summarizes other variables, including percentage flows into equity mutual funds, the log of the inflation adjusted S\&P 500 index value, past nominal stock returns, the log dividend-price ratio, Lettau and Ludvigson's (2001) consumption-wealth ratio, surplus consumption according to Campbell and Cochrane, future 12- and 36-month excess log stock returns, aggregate stock market earnings growth, the unemployment rate, and the number of IPOs.

\begin{tabular}{|c|c|c|c|c|c|c|c|c|}
\hline Variable & Date Range & $\overline{\mathbf{N}}$ & Mean & Median & SD & Min & Max & $\rho$ \\
\hline \multicolumn{9}{|c|}{ Panel A: Raw Measures of Investor Expectations (\%) } \\
\hline Gallup: Main Series & 1996-2011 & 135 & 48.50 & 50.00 & 11.10 & 20.00 & 68.00 & 0.66 \\
\hline \% Expected Return & $1998-2003$ & 51 & 10.63 & 10.21 & 2.47 & 6.52 & 15.56 & 0.86 \\
\hline$\%$ Min Acceptable Return & $1998-2000$ & 14 & 11.52 & 11.32 & 1.02 & 10.33 & 14.57 & 0.14 \\
\hline Graham-Harvey & $2000-2011$ & 42 & 5.95 & 5.98 & 1.62 & 2.18 & 9.21 & 0.49 \\
\hline American Association & 1987-2011 & 294 & 8.54 & 9.25 & 15.67 & -41.00 & 50.47 & 0.63 \\
\hline Investor Intelligence & 1963-2011 & 588 & 12.63 & 14.55 & 19.89 & -49.20 & 66.64 & 0.80 \\
\hline Shiller & 1996-2011 & 132 & 82.03 & 82.17 & 6.42 & 66.99 & 95.62 & 0.87 \\
\hline Michigan & $2000-2005$ & 22 & 9.34 & 8.83 & 1.37 & 7.58 & 12.51 & 0.53 \\
\hline \multicolumn{9}{|c|}{ Panel B: Rescaled Measures of Investor Expectations Used in Return Forecasting Regressions (\% annual) } \\
\hline Gallup* & $1996-2011$ & 135 & 10.49 & 10.73 & 2.27 & 3.94 & 14.27 & 0.66 \\
\hline Graham-Harvey* & $2000-2011$ & 42 & 5.95 & 5.98 & 1.62 & 2.18 & 9.21 & 0.49 \\
\hline American Association* & 1987-2011 & 294 & 10.23 & 10.29 & 1.28 & 6.19 & 13.66 & 0.63 \\
\hline Investor Intelligence* & 1963-2011 & 588 & 10.18 & 10.38 & 2.09 & 3.68 & 15.85 & 0.80 \\
\hline Shiller* & 1996-2011 & 132 & 10.56 & 10.52 & 1.94 & 6.46 & 15.11 & 0.87 \\
\hline Michigan* & 1996-2011 & 22 & 9.35 & 8.83 & 1.37 & 7.58 & 12.51 & 0.53 \\
\hline \multicolumn{9}{|l|}{ Panel C: Other Variables } \\
\hline Flows into Equity Funds & 1984-2011 & 336 & 0.19 & 0.19 & 0.28 & -0.90 & 1.00 & 0.66 \\
\hline $\log (\operatorname{SP} 500)$ & $1963-2011$ & 588 & 6.55 & 6.46 & 0.54 & 5.57 & 7.60 & 0.99 \\
\hline$R_{t-12}$ & $1963-2011$ & 588 & 0.11 & 0.13 & 0.17 & -0.42 & 0.61 & 0.92 \\
\hline $\log (\mathrm{D} / \mathrm{P})$ & 1963-2011 & 588 & -3.60 & -3.52 & 0.41 & -4.59 & -2.86 & 0.98 \\
\hline cay & 1963-2011 & 588 & 0.00 & 0.00 & 0.02 & -0.04 & 0.04 & 0.97 \\
\hline Surplus Consumption & 1963-2011 & 588 & 0.15 & 0.17 & 0.06 & -0.09 & 0.23 & 0.97 \\
\hline$r x_{t+12}$ & $1963-2010$ & 576 & 0.06 & 0.08 & 0.17 & -0.47 & 0.53 & 0.92 \\
\hline$r x_{t+36}$ & 1963-2008 & 552 & 0.18 & 0.15 & 0.34 & -0.51 & 1.19 & 0.96 \\
\hline Earnings Growth (\%) & $1963-2008$ & 612 & 0.02 & 0.05 & 0.38 & -2.17 & 2.17 & 0.98 \\
\hline Unemployment (\%) & $1963-2008$ & 624 & 6.04 & 5.70 & 1.61 & 3.40 & 10.80 & 0.99 \\
\hline NIPOs & $1960-2011$ & 612 & 26.25 & 19 & 23 & 0 & 122 & 0.86 \\
\hline
\end{tabular}


Table 2

Correlations between Different Measures of Investor Expectations

The table shows partial correlation coefficients, i.e., it uses the full sample of overlapping data for each series.

\begin{tabular}{|c|c|c|c|c|c|c|}
\hline & $\begin{array}{r}\text { Gallup } \\
(\mathrm{N}=135)\end{array}$ & $\begin{array}{r}\text { Graham- } \\
\text { Harvey } \\
(\mathrm{N}=42) \\
\end{array}$ & $\begin{array}{r}\text { American } \\
\text { Association } \\
(\mathrm{N}=294) \\
\end{array}$ & $\begin{array}{r}\text { Investor } \\
\text { Intelligence } \\
(\mathrm{N}=588) \\
\end{array}$ & $\begin{array}{r}\text { Shiller } \\
(\mathrm{N}=132)\end{array}$ & $\begin{array}{r}\text { Michigan } \\
(\mathrm{N}=22)\end{array}$ \\
\hline Graham-Harvey & $\begin{array}{c}0.77 \\
{[0.000]}\end{array}$ & & & & & \\
\hline American Association & $\begin{array}{c}0.64 \\
{[0.000]}\end{array}$ & $\begin{array}{c}0.56 \\
{[0.000]}\end{array}$ & & & & \\
\hline Investor Intelligence & $\begin{array}{c}0.60 \\
{[0.000]}\end{array}$ & $\begin{array}{c}0.64 \\
{[0.000]}\end{array}$ & $\begin{array}{c}0.55 \\
{[0.000]}\end{array}$ & & & \\
\hline Shiller & $\begin{array}{c}0.39 \\
{[0.000]}\end{array}$ & $\begin{array}{c}0.66 \\
{[0.000]}\end{array}$ & $\begin{array}{c}0.51 \\
{[0.000]}\end{array}$ & $\begin{array}{c}0.43 \\
{[0.000]}\end{array}$ & & \\
\hline Michigan & $\begin{array}{c}0.61 \\
{[0.003]}\end{array}$ & $\begin{array}{c}-0.12 \\
{[0.922]}\end{array}$ & $\begin{array}{c}0.60 \\
{[0.003]}\end{array}$ & $\begin{array}{c}0.19 \\
{[0.395]}\end{array}$ & $\begin{array}{c}-0.55 \\
{[0.020]}\end{array}$ & \\
\hline Fund Flow & $\begin{array}{c}0.69 \\
{[0.000]}\end{array}$ & $\begin{array}{c}0.71 \\
{[0.000]}\end{array}$ & $\begin{array}{c}0.42 \\
{[0.000]}\end{array}$ & $\begin{array}{c}0.20 \\
{[0.002]}\end{array}$ & $\begin{array}{c}0.51 \\
{[0.001]}\end{array}$ & $\begin{array}{c}0.40 \\
{[0.068]}\end{array}$ \\
\hline
\end{tabular}


Table 3

Determinants of Investor Expectations

Time series regressions of survey expectations of stock market returns for the next year on past stock market returns returns $R$, the price level $\mathrm{P}$ (either log price of S\&P500 or log price-dividend ratio), and measures of fundamental growth:

$$
\operatorname{Exp}_{t}=a+b R_{t-k}+c P_{t}+d Z_{t}+u_{t},
$$

Newey-West $t$-statistics with 12-monthly lags are shown in brackets. GH refers to Graham-Harvey, AA to American Association, and II to Investor Intelligence. In Panel A, the regressions include only past returns and the price level; in Panel B, measures of fundamentals (earnings growth, unemployment, and the risk-free rate) are included.

Panel A: Past Returns and Price Levels

\begin{tabular}{|c|c|c|c|c|c|c|c|c|c|c|c|c|}
\hline & (1) & (2) & (3) & (4) & (5) & (6) & (7) & (8) & (9) & (10) & (11) & $(12)$ \\
\hline & Gallup & $\mathrm{GH}$ & $\mathrm{AA}$ & II & Shiller & Michigan & Gallup & $\mathrm{GH}$ & $\mathrm{AA}$ & II & Shiller & Michigan \\
\hline \multirow[t]{2}{*}{$R_{\mathrm{t}-12}$} & 33.71 & 1.882 & 31.49 & 50.21 & -1.878 & 2.114 & 41.84 & 3.354 & 36.17 & 53.45 & 3.368 & 6.868 \\
\hline & {$[5.790]$} & {$[1.377]$} & [4.522] & {$[6.463]$} & {$[-0.205]$} & {$[2.070]$} & {$[11.72]$} & {$[2.460]$} & [5.839] & {$[7.031]$} & {$[0.691]$} & {$[5.050]$} \\
\hline \multirow[t]{2}{*}{ Log(SP500) } & 16.88 & 4.140 & 11.32 & 8.607 & 9.168 & 6.370 & & & & & & \\
\hline & [3.170] & [2.200] & [2.748] & [2.868] & [1.062] & [4.205] & & & & & & \\
\hline \multirow[t]{2}{*}{$\log (\mathrm{P} / \mathrm{D})$} & & & & & & & 12.99 & 3.404 & 15.72 & 11.46 & 17.80 & 5.389 \\
\hline & & & & & & & [3.446] & [3.264] & [4.234] & [3.131] & [4.808] & [6.359] \\
\hline \multirow[t]{2}{*}{ Constant } & -109.7 & -25.92 & -105.3 & -99.63 & 17.94 & -39.02 & -49.38 & -11.33 & -92.63 & -88.11 & 6.525 & -20.40 \\
\hline & {$[-3.267]$} & {$[-2.065]$} & {$[-3.646]$} & {$[-4.822]$} & {$[0.307]$} & {$[-3.477]$} & {$[-2.952]$} & {$[-2.188]$} & {$[-5.100]$} & {$[-5.293]$} & {$[0.368]$} & {$[-4.257]$} \\
\hline $\mathrm{N}$ & 135 & 42 & 294 & 588 & 132 & 22 & 135 & 42 & 294 & 588 & 132 & 22 \\
\hline$R^{2}$ & 0.616 & 0.285 & 0.218 & 0.242 & 0.044 & 0.735 & 0.632 & 0.348 & 0.259 & 0.243 & 0.317 & 0.827 \\
\hline
\end{tabular}


Panel B: Including Controls for Fundamentals and the Risk-free Rate

\begin{tabular}{|c|c|c|c|c|c|c|c|c|c|c|c|c|}
\hline & $\begin{array}{l}\text { (1) } \\
\text { Gallup }\end{array}$ & $\begin{array}{l}\text { (2) } \\
\mathrm{GH}\end{array}$ & $\begin{array}{l}\text { (3) } \\
\text { AA }\end{array}$ & $\begin{array}{l}\text { (4) } \\
\text { II }\end{array}$ & $\begin{array}{c}(5) \\
\text { Shiller }\end{array}$ & $\begin{array}{c}\text { (6) } \\
\text { Michigan }\end{array}$ & $\begin{array}{c}\text { (7) } \\
\text { Gallun }\end{array}$ & $\begin{array}{l}(8) \\
\mathrm{GH}\end{array}$ & $\begin{array}{l}\text { (9) } \\
\text { AA }\end{array}$ & (10) & $\begin{array}{c}(11) \\
\text { Shiller }\end{array}$ & $\begin{array}{c}(12) \\
\text { Michigan }\end{array}$ \\
\hline & & & & & & & & & & & & \\
\hline$R_{\mathrm{t}-12}$ & & & & & & & $\begin{array}{c}54.95 \\
{[8.761]}\end{array}$ & $\begin{array}{c}7.337 \\
{[8.084]}\end{array}$ & $\begin{array}{c}39.25 \\
{[4.906]}\end{array}$ & $\begin{array}{c}57.87 \\
{[8.038]}\end{array}$ & $\begin{array}{c}3.117 \\
{[0.504]}\end{array}$ & $\begin{array}{c}3.772 \\
{[5.135]}\end{array}$ \\
\hline $\log (\mathrm{P} / \mathrm{D})$ & & & & & & & $\begin{array}{c}17.70 \\
{[3.298]}\end{array}$ & $\begin{array}{c}4.360 \\
{[3.599]}\end{array}$ & $\begin{array}{c}10.80 \\
{[2.006]}\end{array}$ & $\begin{array}{c}6.627 \\
{[1.406]}\end{array}$ & $\begin{array}{c}16.77 \\
{[3.128]}\end{array}$ & $\begin{array}{c}3.978 \\
{[7.222]}\end{array}$ \\
\hline Earnings Gr. & $\begin{array}{c}9.615 \\
{[2.572]}\end{array}$ & $\begin{array}{c}0.272 \\
{[1.154]}\end{array}$ & $\begin{array}{c}5.331 \\
{[2.124]}\end{array}$ & $\begin{array}{c}2.336 \\
{[0.404]}\end{array}$ & $\begin{array}{c}0.753 \\
{[0.833]}\end{array}$ & $\begin{array}{c}2.998 \\
{[4.260]}\end{array}$ & $\begin{array}{c}-7.572 \\
{[-1.966]}\end{array}$ & $\begin{array}{c}-1.215 \\
{[-5.603]}\end{array}$ & $\begin{array}{c}-1.632 \\
{[-0.720]}\end{array}$ & $\begin{array}{c}-6.444 \\
{[-1.882]}\end{array}$ & $\begin{array}{c}-0.626 \\
{[-0.578]}\end{array}$ & $\begin{array}{c}1.580 \\
{[5.068]}\end{array}$ \\
\hline Unemployment & $\begin{array}{c}0.367 \\
{[0.202]}\end{array}$ & $\begin{array}{c}-0.410 \\
{[-2.390]}\end{array}$ & $\begin{array}{c}-3.654 \\
{[-3.146]}\end{array}$ & $\begin{array}{c}1.827 \\
{[1.610]}\end{array}$ & $\begin{array}{c}-3.341 \\
{[-5.118]}\end{array}$ & $\begin{array}{c}0.267 \\
{[0.634]}\end{array}$ & $\begin{array}{c}-1.353 \\
{[-0.765]}\end{array}$ & $\begin{array}{c}-0.0481 \\
{[-0.307]}\end{array}$ & $\begin{array}{c}-1.816 \\
{[-1.367]}\end{array}$ & $\begin{array}{c}1.785 \\
{[1.850]}\end{array}$ & $\begin{array}{c}-2.367 \\
{[-3.595]}\end{array}$ & $\begin{array}{c}-0.180 \\
{[-0.670]}\end{array}$ \\
\hline Risk-free Rate & $\begin{array}{c}190.4 \\
{[1.517]}\end{array}$ & $\begin{array}{c}-8.287 \\
{[-0.486]}\end{array}$ & $\begin{array}{c}-145.7 \\
{[-1.521]}\end{array}$ & $\begin{array}{c}-200.7 \\
{[-3.115]}\end{array}$ & $\begin{array}{c}-246.4 \\
{[-2.774]}\end{array}$ & $\begin{array}{c}82.68 \\
{[3.854]}\end{array}$ & $\begin{array}{c}-103.4 \\
{[-1.374]}\end{array}$ & $\begin{array}{c}-8.103 \\
{[-0.687]}\end{array}$ & $\begin{array}{c}-116.7 \\
{[-1.111]}\end{array}$ & $\begin{array}{c}-186.3 \\
{[-2.887]}\end{array}$ & $\begin{array}{c}-272.4 \\
{[-3.833]}\end{array}$ & $\begin{array}{c}21.48 \\
{[1.404]}\end{array}$ \\
\hline Constant & $\begin{array}{c}-149.1 \\
{[-1.090]}\end{array}$ & $\begin{array}{c}17.01 \\
{[0.932]}\end{array}$ & $\begin{array}{c}181.5 \\
{[1.724]}\end{array}$ & $\begin{array}{c}213.0 \\
{[3.175]}\end{array}$ & $\begin{array}{c}355.1 \\
{[3.765]}\end{array}$ & $\begin{array}{c}-77.22 \\
{[-3.193]}\end{array}$ & $\begin{array}{c}30.62 \\
{[0.352]}\end{array}$ & $\begin{array}{c}-10.72 \\
{[-0.957]}\end{array}$ & $\begin{array}{c}55.23 \\
{[0.434]}\end{array}$ & $\begin{array}{c}110.0 \\
{[1.337]}\end{array}$ & $\begin{array}{c}304.5 \\
{[4.169]}\end{array}$ & $\begin{array}{c}-32.51 \\
{[-2.110]}\end{array}$ \\
\hline$N$ & 135 & 42 & 294 & 588 & 132 & 22 & 135 & 42 & 294 & 588 & 132 & 22 \\
\hline$R^{2}$ & 0.333 & 0.190 & 0.119 & 0.103 & 0.370 & 0.803 & 0.667 & 0.509 & 0.271 & 0.321 & 0.521 & 0.929 \\
\hline
\end{tabular}


Table 4

\section{Relationship between model expected returns and survey expected returns}

The table shows pairwise correlation beteween measures of investor expectations and measures of expected returns. $P$-values and the number of observations are shown directly below each estimate. We use only data where both measures are reported and do not interpolate missing values. $\mathrm{AA}=$ American Association and II=Investor Intelligence.

\begin{tabular}{|c|c|c|c|c|c|c|}
\hline & Gallup & $\begin{array}{r}\text { Graham- } \\
\text { Harvey }\end{array}$ & AA & II & Shiller & Michigan \\
\hline $\log (\mathrm{D} / \mathrm{P})$ & -0.328 & -0.443 & -0.305 & -0.193 & -0.554 & -0.567 \\
\hline$[p$-val $]$ & {$[0.000]$} & {$[0.003]$} & {$[0.000]$} & {$[0.000]$} & {$[0.000]$} & [0.000] \\
\hline$N$ & 135 & 42 & 294 & 588 & 132 & 22 \\
\hline -Surplus C & -0.481 & -0.529 & -0.283 & -0.054 & -0.670 & -0.736 \\
\hline$[p$-val $]$ & {$[0.000]$} & {$[0.000]$} & {$[0.000]$} & [0.191] & {$[0.000]$} & [0.000] \\
\hline$N$ & 135 & 42 & 294 & 588 & 132 & 22 \\
\hline cay & 0.025 & 0.139 & -0.016 & -0.185 & 0.366 & -0.003 \\
\hline$[p$-val $]$ & {$[0.776]$} & {$[0.380]$} & {$[0.788]$} & {$[0.000]$} & {$[0.000]$} & [0.988] \\
\hline$N$ & 135 & 42 & 294 & 588 & 132 & 22 \\
\hline
\end{tabular}


Table 5

\section{Forecasting Future Returns}

We estimate time-series regressions of the form:

$$
R_{t+k}^{x}=a+b X_{t}+u_{t+k}
$$

where $R^{x}$ denotes the $k$-month excess return on the stock market and $X$ is a predictor variable. The independent variables include measures of expectations and measures of expected returns, including cay, the log dividend price ratio, and surplus consumption. Investor expectations variables are starred to indicate that we use the rescaled versions so that they can be interpreted in units of nominal stock returns. Panel A shows results for 12-month returns; Panel B shows 36-month returns. Newey-West-based t-statistics are in brackets. Note that Michigan is excluded from Panel B due to insufficient observations to compute the standard errors. In columns (1)-(6) of Panel A, for each measure of survey expectations we show the p-value on the test that $b=1$.

\section{Panel A. Forecasting 12-month returns}

\begin{tabular}{|c|c|c|c|c|c|c|c|c|c|c|c|c|c|c|c|}
\hline \multirow[t]{2}{*}{ Gallup* } & -1.99 & & & & & & & & & -0.61 & & & & & \\
\hline & {$[-1.371]$} & & & & & & & & & {$[0.433]$} & & & & & \\
\hline \multirow{2}{*}{ Graham-Harvey* } & & -0.021 & & & & & & & & & 0.003 & & & & \\
\hline & & [0.684] & & & & & & & & & [0.111] & & & & \\
\hline \multirow[t]{2}{*}{ American Association* } & & & -1.654 & & & & & & & & & -0.341 & & & \\
\hline & & & [0.888] & & & & & & & & & [0.185] & & & \\
\hline \multirow{2}{*}{ Investor Intelligence* } & & & & -1.542 & & & & & & & & & -1.321 & & \\
\hline & & & & [2.326] & & & & & & & & & [1.993] & & \\
\hline \multirow[t]{2}{*}{ Shiller* } & & & & & -0.625 & & & & & & & & & -4.13 & \\
\hline & & & & & [0.231] & & & & & & & & & [1.676] & \\
\hline \multirow[t]{2}{*}{ Michigan* } & & & & & & -0.081 & & & & & & & & & -0.024 \\
\hline & & & & & & {$[-3.964]$} & & & & & & & & & {$[-1.350]$} \\
\hline \multirow[t]{2}{*}{$\log (\mathrm{D} / \mathrm{P})$} & & & & & & & 0.074 & & & 0.399 & 0.390 & 0.151 & 0.059 & 0.600 & 0.625 \\
\hline & & & & & & & {$[1.475]$} & & & {$[4.414]$} & {$[4.272]$} & {$[1.932]$} & {$[1.137]$} & {$[4.395]$} & {$[4.739]$} \\
\hline \multirow[t]{2}{*}{-Surplus Consumption } & & & & & & & & 0.891 & & & & & & & \\
\hline & & & & & & & & [3.988] & & & & & & & \\
\hline \multirow[t]{2}{*}{ cay } & & & & & & & & & 3.235 & & & & & & \\
\hline & & & & & & & & & [3.153] & & & & & & \\
\hline \multirow[t]{2}{*}{ Constant } & 0.235 & 0.144 & 0.24 & 0.214 & 0.099 & 0.695 & 0.327 & 0.188 & 0.057 & 1.747 & 1.576 & 0.692 & 0.403 & 2.898 & 2.871 \\
\hline & [1.460] & [0.683] & [1.219] & [2.897] & {$[0.371]$} & {$[2.845$} & [1.842] & [5.644] & [3.101] & [5.021] & [6.065] & [2.529] & [2.172] & [3.917] & [5.791] \\
\hline$[p$-val, $b=1]$ & {$[0.040]$} & {$[0.000]$} & {$[0.154]$} & {$[0.000]$} & {$[0.550]$} & {$[0.000]$} & & & & & & & & & \\
\hline$N$ & 131 & 38 & 282 & 576 & 120 & 22 & 612 & 612 & 610 & 131 & 38 & 282 & 576 & 120 & 22 \\
\hline$R^{2}$ & 0.057 & 0.031 & 0.015 & 0.036 & 0.004 & 0.342 & 0.031 & 0.111 & 0.111 & 0.299 & 0.207 & 0.104 & 0.056 & 0.298 & 0.696 \\
\hline
\end{tabular}


Table 5 [Continued]

\section{Forecasting Future Returns}

Panel B. Forecasting 36-month returns

\begin{tabular}{|c|c|c|c|c|c|c|c|c|c|c|c|c|c|}
\hline \multirow[t]{2}{*}{ Gallup* } & -6.185 & & & & & & & & -5.483 & & & & \\
\hline & {$[3.509]$} & & & & & & & & {$[2.591]$} & & & & \\
\hline \multirow[t]{2}{*}{ Graham-Harvey } & & -0.010 & & & & & & & & 0.000 & & & \\
\hline & & {$[0.303]$} & & & & & & & & {$[0.004]$} & & & \\
\hline \multirow[t]{2}{*}{ American Association* } & & & -3.329 & & & & & & & & 1.321 & & \\
\hline & & & {$[0.838]$} & & & & & & & & {$[0.382]$} & & \\
\hline \multirow[t]{2}{*}{ Investor Intelligence* } & & & & -5.173 & & & & & & & & -4.631 & \\
\hline & & & & [3.126] & & & & & & & & {$[2.656]$} & \\
\hline \multirow[t]{2}{*}{ Shiller* } & & & & & -3.679 & & & & & & & & -4.521 \\
\hline & & & & & [1.249] & & & & & & & & [1.732] \\
\hline \multirow[t]{2}{*}{$\log (\mathrm{D} / \mathrm{P})$} & & & & & & 0.194 & & & 0.49 & 0.183 & 0.525 & 0.145 & 0.247 \\
\hline & & & & & & {$[1.612]$} & & & {$[1.268]$} & {$[0.855]$} & {$[2.285]$} & [1.132] & [0.861] \\
\hline \multirow[t]{2}{*}{ Surp } & & & & & & & 2.959 & & & & & & \\
\hline & & & & & & & [3.737] & & & & & & \\
\hline \multirow[t]{2}{*}{ cay } & & & & & & & & 12.537 & & & & & \\
\hline & & & & & & & & [4.998] & & & & & \\
\hline \multirow[t]{2}{*}{ Constant } & 0.668 & 0.084 & 0.576 & 0.703 & 0.423 & 0.882 & 0.634 & 0.166 & 2.649 & 0.773 & 2.141 & 1.167 & 1.526 \\
\hline & {$[3.362]$} & {$[0.429]$} & {$[1.553]$} & {$[3.571]$} & {$[1.282]$} & {$[2.127]$} & {$[4.428]$} & {$[3.871]$} & {$[1.623]$} & {$[0.888]$} & {$[2.782]$} & {$[2.634]$} & [1.191] \\
\hline$N$ & 121 & 30 & 258 & 552 & 96 & 588 & 588 & 586 & 121 & 30 & 258 & 552 & 96 \\
\hline$R^{2}$ & 0.158 & 0.004 & 0.012 & 0.105 & 0.06 & 0.056 & 0.232 & 0.406 & 0.252 & 0.02 & 0.23 & 0.136 & 0.079 \\
\hline
\end{tabular}




\section{Table 6}

\section{Forecasting Stock Market Returns Using Simulated Data}

We simulate stock prices when the demands of fundamental and positive feedback traders are given by:

$$
s_{f, t}=p_{t}-0.75 f_{t}-0.25 f_{t-1} \text {, and } s_{p, t}=0.17 p_{t}+0.34\left(p_{t}-p_{t-1}\right) .
$$

The table shows time-series regressions of the form:

$$
R_{t+k}=p_{t+k}-p_{t}=a+b X_{t}+u_{t+k},
$$

estimated on the simulated data. The fundamental $f$ is a random walk with mean zero and standard deviation of one. We run the simulation for 100 data points and keep only the last 50. $p$-value corresponds to the fraction of samples for which the estimated coefficient is greater than zero (or less than zero in the case of

\begin{tabular}{|c|c|c|c|c|c|c|c|c|c|c|c|c|}
\hline \multirow{2}{*}{$\begin{array}{l}\text { Dep Var: } \\
\text { Horizon: }\end{array}$} & \multicolumn{3}{|c|}{$X=f-p$} & \multicolumn{3}{|c|}{$X=z$} & \multicolumn{3}{|c|}{$X=f$} & \multicolumn{3}{|c|}{$X=f-\operatorname{mav}(f, 10)$} \\
\hline & $R_{t+1}$ & $R_{t+2}$ & $R_{t+3}$ & $R_{t+1}$ & $R_{t+2}$ & $R_{t+3}$ & $R_{t+1}$ & $R_{t+2}$ & $R_{t+3}$ & $R_{t+1}$ & $R_{t+2}$ & $R_{t+3}$ \\
\hline$b$-mean & 1.040 & 0.761 & 0.913 & -0.560 & -0.525 & -0.690 & -1.366 & -0.985 & -1.147 & -6.484 & -5.435 & -6.945 \\
\hline$[t$-mean $]$ & [5.580] & [4.105] & [4.601] & [-1.829] & {$[-2.011]$} & {$[-2.439]$} & {$[-5.681]$} & {$[-4.056]$} & {$[-4.353]$} & {$[-1.877]$} & {$[-1.766]$} & {$[-2.065]$} \\
\hline$[p$-val $]$ & {$[0.000]$} & {$[0.000]$} & {$[0.000]$} & {$[0.000]$} & {$[0.016]$} & {$[0.014]$} & {$[0.000]$} & {$[0.000]$} & {$[0.000]$} & {$[0.002]$} & {$[0.038]$} & {$[0.044]$} \\
\hline $\operatorname{Avg} R^{2}$ & 0.385 & 0.260 & 0.303 & 0.073 & 0.087 & 0.122 & 0.395 & 0.255 & 0.281 & 0.077 & 0.074 & 0.099 \\
\hline
\end{tabular}
the average coefficient value being negative). 
Table 7

Equity Issuance and Stock Market Expectations

We estimate time-series regressions of the form:

$$
N I P O_{t}=a+b X_{t}+u_{t},
$$

where NIPO denotes the number of IPOs in month $t$ and $X$ alternately denotes survey expectations of future returns (Gallup, Graham-Harvey, American Association, Investor Intelligence, Shiller, or Michigan) or monthly flows into equity-oriented mutual funds. Newey-West-based $t$-statistics, based on 12 months of lags, are in brackets.

\begin{tabular}{|c|c|c|c|c|c|c|c|}
\hline Gallup & $\begin{array}{r}0.514 \\
{[4.360]}\end{array}$ & & & & & & \\
\hline Graham-Harvey & & $\begin{array}{r}1.689 \\
{[1.847]}\end{array}$ & & & & & \\
\hline American Association & & & $\begin{array}{r}0.34 \\
{[2.161]}\end{array}$ & & & & \\
\hline Investor Intelligence & & & & $\begin{array}{r}0.064 \\
{[0.559]}\end{array}$ & & & \\
\hline Shiller & & & & & $\begin{array}{r}-0.386 \\
{[0.722]}\end{array}$ & & \\
\hline Michigan & & & & & & $\begin{array}{r}3.682 \\
{[8.229]}\end{array}$ & \\
\hline Flows & & & & & & & $\begin{array}{r}4,342.51 \\
{[8.989]}\end{array}$ \\
\hline Constant & $\begin{array}{r}8.88 \\
{[4.196]}\end{array}$ & $\begin{array}{r}3.021 \\
{[0.530]}\end{array}$ & $\begin{array}{r}23.984 \\
{[6.693]}\end{array}$ & $\begin{array}{r}25.355 \\
{[7.802]}\end{array}$ & $\begin{array}{l}45.254 \\
{[0.990]}\end{array}$ & $\begin{array}{l}-24.608 \\
{[4.885]}\end{array}$ & $\begin{array}{r}22.132 \\
{[7.157]}\end{array}$ \\
\hline$N$ & 131 & 38 & 282 & 576 & 120 & 22 & 324 \\
\hline$R^{2}$ & 0.362 & 0.099 & 0.062 & 0.003 & 0.037 & 0.424 & 0.260 \\
\hline
\end{tabular}

